University of South Florida

DIGITAL COMMONS @ UNIVERSITY OF SOUTH FLORIDA
Digital Commons @ University of

South Florida

$10-1-2001$

\title{
Neighborhood Intermodal Transfer Facilities
}

CUTR

Follow this and additional works at: https://digitalcommons.usf.edu/cutr_nctr

\section{Recommended Citation}

"Neighborhood Intermodal Transfer Facilities," National Center for Transit Research (NCTR) Report No. CUTR-NCTR-RR-2000-08, Center for Urban Transportation Research, University of South Florida, 2001. DOI: https://doi.org/10.5038/CUTR-NCTR-RR-2000-08

Available at: https://scholarcommons.usf.edu/cutr_nctr/27

This Technical Report is brought to you for free and open access by the National Center for Transit Research (NCTR) Archive (2000-2020) at Digital Commons @ University of South Florida. It has been accepted for inclusion in Research Reports by an authorized administrator of Digital Commons @ University of South Florida. For more information, please contact digitalcommons@usf.edu. 


\title{
Neighborhood Intermodal Transfer Facilities \\ Final Report
}

\author{
Prepared by the
}

\section{National Center for Urban Transportation Research at the \\ Center for Urban Transportation Research \\ University of South Florida}

October 2001 
TECHNICAL REPORT STANDARD TITLE PAGE

\begin{tabular}{|c|c|c|c|}
\hline $\begin{array}{l}\text { 1. Report No. } \\
\text { NCTR-392-16 }\end{array}$ & 2. Government Accession No. & \multicolumn{2}{|c|}{ 3. Recipient's Catalog No. } \\
\hline \multirow{2}{*}{\multicolumn{2}{|c|}{$\begin{array}{l}\text { 4. Title and Subtitle } \\
\text { Neighborhood Intermodal Transfer Facilities }\end{array}$}} & \multicolumn{2}{|c|}{$\begin{array}{l}\text { 5. Report Date } \\
\text { October } 2001\end{array}$} \\
\hline & & \multicolumn{2}{|c|}{ 6. Performing Organization Code } \\
\hline \multicolumn{2}{|c|}{$\begin{array}{l}\text { 7. Author(s) } \\
\text { Laurel Land and Chandra Foreman }\end{array}$} & \multicolumn{2}{|c|}{$\begin{array}{l}\text { 8. Performing Organization Report } \\
\text { No. }\end{array}$} \\
\hline \multirow{2}{*}{\multicolumn{2}{|c|}{$\begin{array}{l}\text { 9. Performing Organization Name and Address } \\
\text { National Center for Transit Research (NCTR) } \\
\text { University of South Florida } \\
4202 \text { E. Fowler Ave., CUT 100, Tampa, FL 33620-5375 }\end{array}$}} & \multicolumn{2}{|l|}{ 10. Work Unit No. } \\
\hline & & \multicolumn{2}{|c|}{$\begin{array}{l}\text { 11. Contract or Grant No. } \\
\text { DTRS98-G-0032 }\end{array}$} \\
\hline \multirow{3}{*}{\multicolumn{2}{|c|}{$\begin{array}{l}\text { 12. Sponsoring Agency Name and Address } \\
\text { Research \& Special Programs Admin., U.S. Department of Tr } \\
\text { RSPA/DIR-1, Room } 8417,4007^{\text {th }} \text { Street SW, Washington, D. } \\
\text { Florida Department of Transportation } \\
605 \text { Suwannee Street, MS 26, Tallahassee, FL 32399-0450 }\end{array}$}} & \multirow{2}{*}{\multicolumn{2}{|c|}{$\begin{array}{l}\text { 13. Type of Report and Period } \\
\text { Covered }\end{array}$}} \\
\hline & & & \\
\hline & & \multicolumn{2}{|c|}{ 14. Sponsoring Agency Code } \\
\hline \multicolumn{4}{|c|}{$\begin{array}{l}\text { 15. Supplementary Notes } \\
\text { Supported by a grant from the Florida Department of Transportation and the U.S. Department of } \\
\text { Transportation. }\end{array}$} \\
\hline \multicolumn{4}{|c|}{$\begin{array}{l}\text { 16. Abstract } \\
\text { Intermodalism is a topic that is fostered in the Transportation Efficiency Act for the } 21^{\text {st }} \text { Century and } \\
\text { Florida's Growth Management Act; however, it can also be difficult to achieve. For this reason, it is } \\
\text { important to develop new ideas and concepts that can be used to further the hope of diminishing } \\
\text { continued problems associated with America's love of the automobile and its superior convenience. } \\
\text { Through its National Center for Transit Research, and under contract with the Florida Department of } \\
\text { Transportation, the Center for Urban Transportation Research was tasked with reviewing selected } \\
\text { small-scale transfer facilities, focusing on the interaction of transportation modes (e.g., bicycle, } \\
\text { pedestrian, bus, park and ride). The purpose of the review is to determine the minimum characteristics } \\
\text { required for establishing intermodal transfer facilities in neighborhoods, and the feasibility and } \\
\text { implementation of such facilities. }\end{array}$} \\
\hline $\begin{array}{l}\text { 17. Key Words } \\
\text { Transit, Intermodal, } \\
\text { Transfer Facilities }\end{array}$ & $\begin{array}{l}\text { 18. Distribution Statement } \\
\text { Available to the public through th } \\
\text { Information Service (NTIS), } 5285 \\
\text { Springfield, VA } 22161,703-605 \\
\text { An electronic version of this doct } \\
\text { the public in .pdf format through } \\
\text { http://www.nctr.usf.edu/. }\end{array}$ & $\begin{array}{l}\text { ational Tech } \\
\text { rt Royal Roa } \\
0, \text { http://wn } \\
\text { nt is also av } \\
\text { NCTR web }\end{array}$ & $\frac{\text { tis.gov/ }}{\text { le to }}$ \\
\hline $\begin{array}{l}\text { 19. Security Classif. (of this report) } \\
\text { Unclassified }\end{array}$ & $\begin{array}{l}\text { 20. Security Classif. (of this page) } \\
\text { Unclassified }\end{array}$ & $\begin{array}{l}\text { 21. No. of pages } \\
82\end{array}$ & 22. Price \\
\hline
\end{tabular}

Form DOT F 1700.7 (8-69) 


\title{
Neighborhood Intermodal Transfer Facilities
}

\author{
Prepared by: \\ Laurel Land \\ Chandra Foreman \\ National Center for Transit Research \\ Center for Urban Transportation \\ University of South Florida \\ 4202 E. Fowler Avenue, CUT 100 \\ Tampa, Florida 33620-5375 \\ (813) 974-3120 \\ http://www.nctr.usf.edu/ \\ Program Manager: \\ Amy Datz, FDOT \\ Contract Number BC137-18 \\ Florida Department of Transportation \\ 605 Suwannee Street \\ Tallahassee, Florida 32399-0450 \\ (850) 414-4500 \\ http://www.dot.state.fl.us/
}

Research and Special Program Administration

U.S. Department of Transportation

RSPA/DIR-1, Room 8417

$4007^{\text {th }}$ Street, SW

Washington, DC 20590

http://www.rspa.dot.gov/

The opinions, findings and conclusions expressed in this publication are those of the authors and not necessarily those of the Florida Department of Transportation or the U.S. Department of Transportation.

This document was prepared in cooperation with the State of Florida Department of Transportation and the U.S. Department of Transportation. 


\section{Neighborhood Intermodal Transfer Facilities}

\section{Preface}

The Florida Department of Transportation (FDOT) has requested, under the National Center for Transit Research (NCTR) at the Center for Urban Transportation Research (CUTR) at the University of South Florida, a review of selected existing small-scale intermodal transfer facilities to determine the minimum characteristics required for establishing intermodal transfer facilities in neighborhoods. Beyond identifying the minimum standards for success, the purpose of this study was to provide transportation agencies with feasible alternatives, outlined with costs, when developing neighborhoodscale transportation facilities that focus on the interaction of transportation modes.

The following CUTR staff assisted in conducting the research, analysis, and preparation of this report:

Principal Investigator: Laurel Land, AICP, Research Associate

Research Assistance: Chandra Foreman, AICP, Research Associate 
Table of Contents

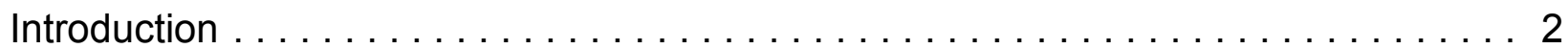

Organization of the Report $\ldots \ldots \ldots \ldots \ldots \ldots \ldots \ldots \ldots \ldots \ldots \ldots$

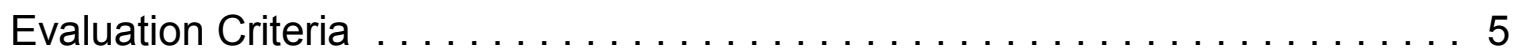

Section I-Case Studies . . . . . . . . . . . . . . . . . . . . . . . 10

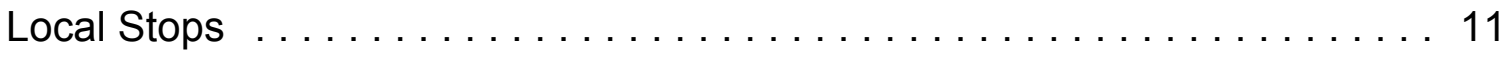

Margate Inner-City Transit (MIT) Terminal $\ldots \ldots \ldots \ldots \ldots \ldots \ldots 11$

Washington Shores Superstop . . . . . . . . . . . . . . . 16

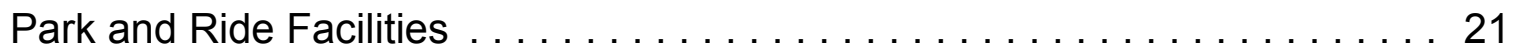

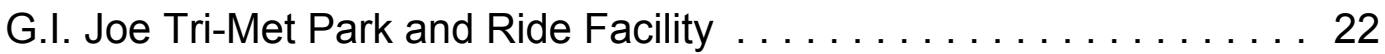

Transit Centers . . . . . . . . . . . . . . . . . . . . . . 28

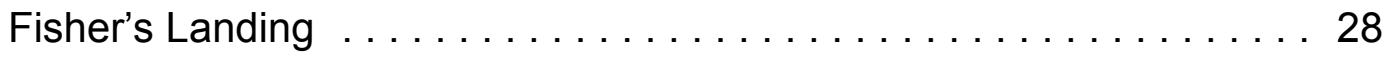

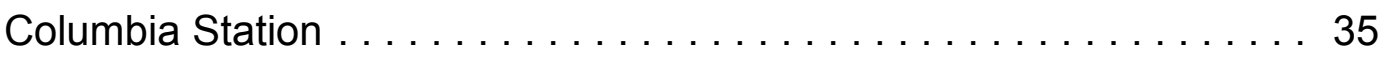

Rail Stations . . . . . . . . . . . . . . . . . . . . . . 39

Wellston MetroLink Station $\ldots \ldots \ldots \ldots \ldots \ldots \ldots \ldots \ldots \ldots$

Section II - Common Findings $\ldots \ldots \ldots \ldots \ldots \ldots \ldots \ldots \ldots \ldots \ldots \ldots$

Section III - Implications for Neighborhood Intermodal Facilities in Florida . . . . . . 62

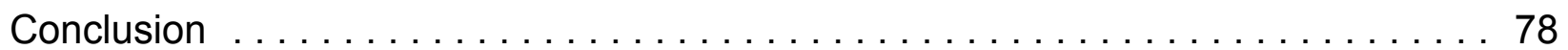

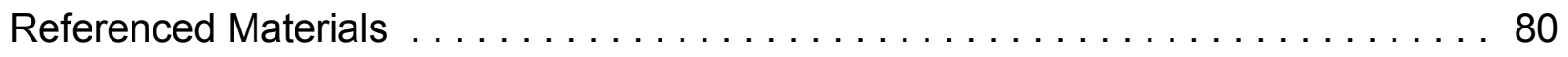

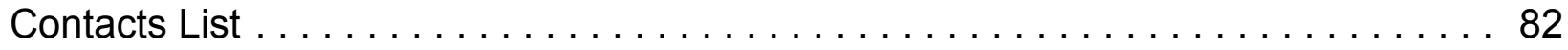

Appendix - Questions to Guide Interviews and Site Visits . . . . . . . . A A-1 
Neighborhood Intermodal Transfer Facilities

\section{INTRODUCTION}

The Florida Department of Transportation (FDOT), under the National Center for Transit Research (NCTR), requested that the Center for Urban Transportation Research (CUTR) at the University of South Florida examine existing small-scale transfer facilities, focusing on the interaction of transportation modes. The purpose of such research was to determine which common characteristics that exist among the case examples can be attributed to the success of those facilities, and can further be used in the creation of neighborhood intermodal transfer facilities in Florida.

The concept of "livable communities" has had impressive influence on many of the newer developments in this country over the past ten years. Those developments that have managed to improve the quality of life by providing safe and economically vibrant neighborhoods while projecting a positive image usually had one thing in common integration or inclusion of mobility alternatives. These mobility options focus on and allow for the integration of bus, bicycle, pedestrian, rail, and park and ride lots as alternatives to the single-occupant vehicle.

Intermodalism is an important feature of today's transportation systems, which is evident by its stature in the Transportation Efficiency Act for the $21^{\text {st }}$ Century and Florida's Growth Management Act. The renewed interest in transit-oriented development has also encouraged intermodalism. While the love affair with the automobile remains strong, there are record number of Americans willing to trade in their single-occupant vehicle commutes for alternative transportation. Whether for physical fitness, cost-efficiency, or state of mind, many people are choosing to use transit, walk, ride a bicycle, carpool, or participate in a combination of these modes to get to work, shop, or play. Most of the championed examples of intermodalism are in downtown or major activity centers. Little attention has been paid to neighborhood-scale intermodal facilities and their requirements for effectiveness. The effectiveness of an intermodal facility is not just a function of its size. 
Rather, it is a function of the facility's ability to provide intermodal interaction. Transportation agencies should create intermodal transfer facilities on a scale that is functional and enhancing to a neighborhood, rather than invasive or disenfranchising. These facilities should encourage a safe environment for pedestrian and bicycle traffic, as well as other modes prevalent on a community scale.

This report contains specific examples of intermodal transfer facilities of various types and scale. The facility types explored are local stops, park and ride lots, transit centers, and rail stations. The focus of the facilities relates to the interaction of transportation modes, with particular attention given to bicycle, pedestrian, bus, and park and ride, which are the primary modes utilized in a neighborhood setting.

Initially, the internet and current transportation journals were used to create a list of possible site examples of transfer facilities that integrate various transportation modes. The facilities eventually selected to serve as examples were chosen based on factors, such as:

- Demonstrates a functional link between transit and the community.

- Exhibits transferability, with regard to facility design and functions, particularly in Florida.

- Represents variable facility types, including a local stop, transit center, park and ride lot, and rail station.

- $\quad$ Exhibits intermodal features or could be adapted to do so.

- Represents a variety of locations, facility size, mode mix, and community support.

- Represents a range in cost and a variety of funding sources.

- Impacts the community and/or impacted by the community.

- Overcomes obstacles in planning, development, or operations.

- Develops creative amenities and prioritized safety considerations.

- Promotes partnerships within and surrounding the facility. 
- Demonstrates extraordinary public involvement.

Once the initial list of possible site examples was developed, information was collected relating to the design, construction, and success of each example. After further purging of the list, brief e-mail questionnaires were sent to people responsible for planning, developing, maintaining, and operating the transfer facilities to gain a better understanding of their design and operation. Follow-up phone interviews were also conducted, when necessary. The questionnaires and follow-up phone interviews provided general information on the planning, developing, operations, and maintenance of the transfer facility. The questions that were used to guide the telephone interviews are included in the appendix. Eventually, six sites were selected for this report. Interviews and/or site visits were conducted to gather additional information regarding geographic and demographic data, site design, planning process, community involvement, and funding.

\section{Organization of the Report}

This report is organized into three sections. Section I, Case Studies, describes the selected sites by facility type. The case studies include a profile of the area and details of the site, which provides insight into how well they each met the criteria presented above. Specifically, planning and facility design, description of surrounding activities, and costs and funding sources are discussed. Community involvement processes are also described.

Section II, Common Findings, includes a synthesis of the findings and acknowledges those common characteristics that were instrumental in the success of each facility. Further, the criteria described above are used to evaluate each facility.

Section III, Implications for Neighborhood Intermodal Facilities in Florida, identifies which aspects of the case studies could be replicated or modified in the development of 
neighborhood-scale intermodal transfer facilities in Florida, with emphasis on how the facilities may affect or be affected by Florida's unique demographic and physical environment. The conclusion presents findings as a practical implementation guide, summarizing practices in planning, community involvement processes, design, operations, maintenance, and cost/funding.

\section{Evaluation Criteria}

The facilities were evaluated on how well each was developed with regard to coordination of modes, physical location, design, and safety. Other factors also considered include safety, service reliability, user satisfaction, physical attractiveness, community acceptance, and costs. Table 1 identifies criteria which were used to qualitatively evaluate the effectiveness of the intermodal transfer facilities presented in this report. Examples of measures for similar criteria are described in Alternatives for Intermodal Improvements in Miami-Dade County. ${ }^{1}$ The Miami-Dade MPO sponsored a study to identify 25 potential intermodal center sites. A description of the criteria used in this report and how they were used to measure the effectiveness of the site examples follows Table 1.

\footnotetext{
${ }^{1}$ Kimley-Horn and Associates, Inc. 1998. Alternatives for Intermodal Improvements in Miami-Dade County: Final Report. Miami: Miami-Dade County Metropolitan Planning Organization.
} 
Neighborhood Intermodal Transfer Facilities

Table 1: Criteria for Effectiveness in Developing an Intermodal Transfer Facility

\begin{tabular}{|r|l|}
\hline 1 & Intermodal interaction is supported and safe \\
\hline 2 & Facility type and size reflect community needs \\
\hline 3 & Amenities enhance the users' experiences \\
\hline 4 & $\begin{array}{l}\text { Facility is accessible to everyone and compliant with the Americans with Disabilities } \\
\text { Act (ADA) }\end{array}$ \\
\hline 5 & Transferability between modes is feasible and reliable \\
\hline 6 & Reliable passenger information and service are provided \\
\hline 7 & Community involvement is integrated in the planning and design \\
\hline 8 & Opportunities for community partnerships exist \\
\hline
\end{tabular}

Criterion One -- Intermodal interaction is supported and safe: According to Evaluation of Intermodal Passenger Transfer Facilities, ${ }^{2}$ locating an intermodal transfer facility is summarized by two rules: maximize the ease of access from modes and maximize potential transfers between modes. The study acknowledges that "an intermodal facility will ultimately be judged by its ability to serve passengers, and its location is critical to the quality of that service (p. 41)." An intermodal transfer facility should be located such that connections within a single mode and between various modes are available. Modal support will obviously reflect the transportation alternatives available for the area; however, at a minimum, the pedestrian mode should be supported. Site selection also involves identifying mode requirements to determine compatibility. Inappropriate site selection can doom the success of the facility.

Design of an intermodal transfer facility should also incorporate safety mechanisms that prevent incidents between modes. Evaluation of access and egress is critical in ensuring that the modes are compatible and that the facility can operate effectively and efficiently. It is also important to ensure that the facility design does not pose physical barriers to

${ }^{2}$ Horowitz, Alan and Nick Thompson. 1994. Evaluation of Intermodal Passenger Transfer Facilities, Final Report. Washington, DC: Federal Highway Administration, DOT-T-95-02. 
Neighborhood Intermodal Transfer Facilities

transferring between modes. A simple example of such a barrier is to have an intermodal transfer facility without bicycle storage area. This criterion was measured by identifying the number of modes and routes served and by evaluating facility layout and engineering considerations.

Criterion Two - Facility type and size reflect community needs: When rail or other infrastructure-driven modes are to be involved in an intermodal center, the type of facility is most determined by the requirements of that mode (the most intense mode). However, for modes most commonly found in neighborhoods, such as bus, pedestrian, bicycle, and park and ride the options for facility type will also be determined by available funding, demand for service, and community needs. Facility developers may find that inadequate funding limits facility types to on-street local stops or that passenger demand may require a facility with several bays and personnel on duty. Placing a facility of inappropriate scale in a community is either wasteful or easily outgrown and may create an unsafe environment. This criterion was measured by evaluating how the facility space or lack of facility space affected intermodal objectives.

Criterion Three - Amenities enhance the users' experiences: Some amenities are arguably not amenities at all. Rather, many design and site furnishings are considered necessities, especially for the choice user. Transit signs, system/route maps and information, trash receptacles, and lighting are required to ensure that patrons are afforded reasonable opportunity to plan and complete their trip in a safe environment. Even amenities such as shelters, benches, and public telephones provide some necessary comfort, especially where poor weather conditions or elderly patronage is common. Other amenities, such as landscaping, public art displays, and vending services also contribute to the comfort of the facility user. Amenities have an important role in the effectiveness of a facility. This criterion was measured by identifying the presence and effectiveness of features at a facility. 
Neighborhood Intermodal Transfer Facilities

Criterion Four - Facility is accessible to everyone and compliant with the Americans with Disabilities Act (ADA): Any developer of transit facilities is responsible for ensuring that it is accessible to all persons, including those with physical disabilities. Compliance with the ADA is an absolute necessity when designing an intermodal transfer facility. Attention to amenities should also be given with regards to accessibility by ensuring that information is accessible to hearing- and sight-impaired users. Identifying the level of difficulty or effort required in accessing all aspects of the facility is one way accessibility was measured.

Criterion Five -Transferability between modes is feasible and reliable: Those facilities which provide the most chances for transfers between modes and routes afford patrons the greatest opportunity to maximize transportation alternatives. Failure of any of the participating modes can affect the intent of the facility and reduce the ability of the patrons to maximize transportation alternatives. For example, a flooded park and ride lot could effectively eliminate carpooling, vanpooling, and transit use and, in other words, impact the transferability between modes. Facilities in pursuit of barrier-free transfers also make attempts to coordinate the fare medium of the various transportation modes. This criterion was measured by evaluating the attempt at and success of coordinating routes, modes, and fare requirements.

Criterion Six-Reliable passenger information and service are provided: Probably one of the greatest measures of success of a transit facility has more to do with the service provided at that facility, than the facility itself. For instance, a state-of-the-art bus facility that does not have reasonable bus service to major destinations is useless to many customers. On the other hand, use of service to major destinations will not be maximized if plentiful and accurate information is not available at the facility. This was measured by evaluating the source, detail level, and accuracy of route and mode information at a facility. 
Criterion Seven - Community involvement is integrated into the planning and design: Some opponents to transit facilities are concerned that the facilities detract from their communities and such concerns can be the impetus to significant neighborhood resistance to potential facility development. By inviting the public to participate in the planning and design of the intermodal transfer facility, the developing agency has the ability to minimize or eliminate some controversies before they leave a permanent scar on the development of the project. The impact that the facility might have on the neighborhood is a legitimate concern of those in the community. Consequently, when the community is not consulted or at least informed of major changes, buy-in is much more difficult. It is also important to maintain promises (or adequately explain changes to plans) made to a community regarding the planning and design of a facility. This criterion was measured by identifying opportunities for participation and the level of participation, as well as identifying what role public input played in the overall design of the facility.

Criterion Eight - Opportunities for community partnerships exist: Generating support should go beyond involving residents of the area. Recruiting other public and private partners to invest in the transit facility and surrounding community is another method of achieving support. Throughout the country, it is becoming more evident that coordinating transportation alternatives in one place brings people to that location. As a result, there are more opportunities for transit and neighboring activities to form partnerships that enhance the livability of those in the area. The impact of partnerships can be seen in the non-transit related developments that are burgeoning around transit facilities. This criterion was measured by identifying the number and types of partners involved in enhancing the transit facility or the area around it, as well as by identifying the value of the partners' contributions. 


\section{Section I}

\section{Case Studies}

Examples of small-scale intermodal transfer facilities were difficult to find. Most communities have transfer facilities that exhibit some form of intermodalism. Transfer facilities that were identified in the review were either small-scale with limited intermodal interaction or of greater size with interaction of multiple modes. It seemed important not to discount a facility for its intermodal simplicity, nor did it seem appropriate to ignore those facilities that were larger than the neighborhood scale. The primary modes at most of the sites were transit and pedestrian or transit and park and ride. In addition, what might be considered small-scale in one area was not necessarily considered small-scale for others. Varying types of transit facilities were purposely selected so that differing levels of scale and mode mix could be evaluated. The six sites selected for case study were:

- $\quad$ local stops - Orlando and Margate, Florida

- $\quad$ park and ride facility - Portland, Oregon

- transit centers - Vancouver and Wenatchee, Washington

- $\quad$ rail station - St. Louis, Missouri

Each of these sites met some aspects of the criteria by being either: (1) small and intermodal, (2) small, but not intermodal; or (3) intermodal, but not small. However, each was determined to be quite useful for this study and had potential implications for models in Florida. The premise when selecting the case studies was that some aspect of each selected facility could be instrumental in creating a model to be used in improving intermodal interaction on a smaller scale in neighborhood or small community settings.

\section{Local Stops}


Neighborhood Intermodal Transfer Facilities

Historically, when a transit agency has wanted to provide bus service in a small residential area, little more than a shelter with adequate signage was usually needed or wanted. The typical bus stop has served many communities well by providing an identifiable point at which residents may wait for a bus. Although the intermodal needs of a community may increase, it does not necessarily mean that a transit stop facility must also grow in size. Some transit agencies have had success in placing neighborhood stops without causing great delays in the schedule with layover areas and intricate maneuvers through off-street facilities. Others have been able to create off-street facilities that blend with the community and are seen as an enhancement to the area. Two examples of community bus stops are described below. The Margate Inner-City Terminal, located in Broward County, Florida is the more typical on-street bus stop; while, the Washington Shores Lynx facility in Orlando, Florida is an off-street transit facility in the heart of a residential community.

\section{Margate Inner-City Transit (MIT) Terminal}

The City of Margate, Florida is one of several communities participating in the Community Bus Service program through Broward County Transit (BCT). The Community Bus Service was initiated in 1991 to increase the number of destinations within the city limits of participating communities that can be reached using public transit. Feeder bus services

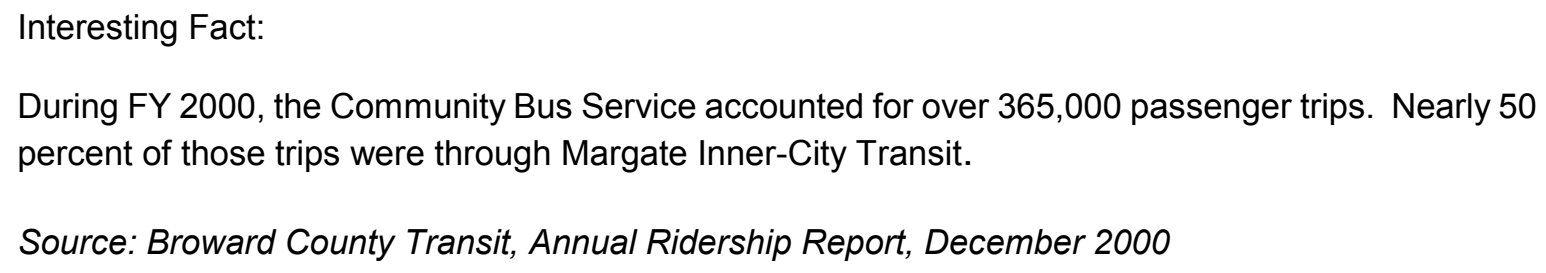

provide connections to BCT fixed routes. Through this program, BCT currently funds eleven community bus systems using some of the revenue from two penny gas tax options successfully levied by the Broward County Board of Commissioners. Some of the revenue 
funds are used by BCT to purchase vehicles, which are leased to participating communities for ten dollars each per year. In addition, the communities are given twenty dollars per revenue hour to assist with operating expenses. Margate has the most advanced community bus service of all the participating municipalities. The Margate InnerCity Transit Service has been participating in the Community Bus Service since 1993.

The Margate Terminal was selected as an example to demonstrate the ability of small transit systems to provide effective transfer facilities while utilizing limited resources. The approach of BCT in developing a cooperative effort to increase its service area while

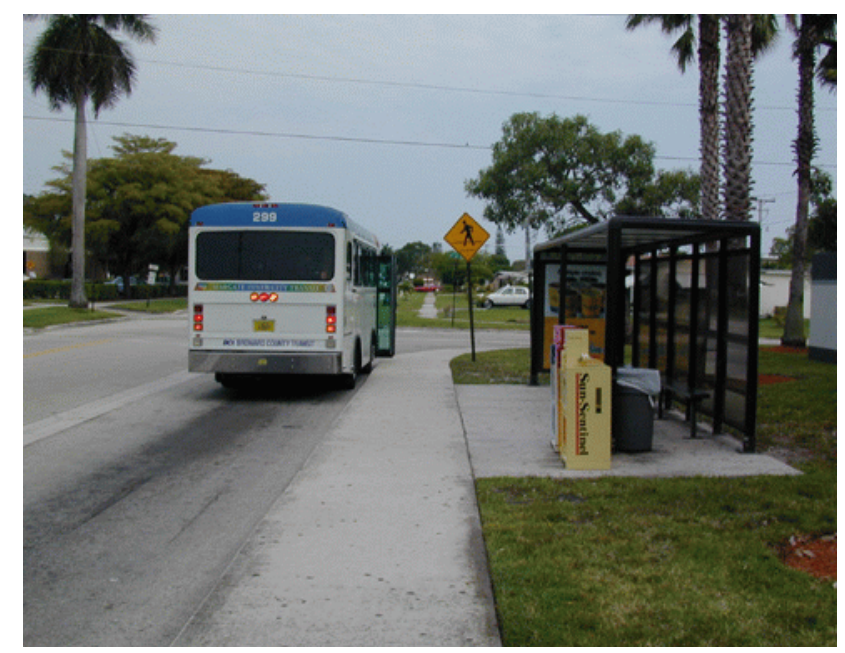

Margate is one of eleven communities participating in Broward County Transit's Community Bus Service.

allowing some autonomy by the local communities that are participating in the Community Bus Service is also encouraging.

Prior to the inception of the Community Bus Service, BCT provided service throughout Margate and made several daily trips to the Margate Terminal located on Park Drive, which is a two-lane road near Margate City Hall and the public library. When the Community Bus Service was initiated in Margate, BCT continued to provide service to and from the Margate Terminal, but soon decided that between the MIT and BCT buses, as well as other shuttle services using the facility, the area had become too congested. Occasionally, there were 
as many as three 40 -foot BCT buses and three 26 -foot MIT buses at the terminal at the same time. This resulted in passengers darting between buses trying to make connections. In the last year, BCT discontinued service at the Margate Terminal, but stops a block down at Margate Boulevard. This compromise has reduced the bus traffic in the area near the public library and City Hall, while also maintaining a reasonable connection point between the terminal and the BCT routes.

Margate Inner-City Transit maintains four routes (Routes A, B, C, and D), all serving the Margate Terminal. These routes cover 68 daily round trips throughout the Margate community. Service operates Monday through Saturday from 7:15 a.m. until 6:50 p.m. The Margate Inner-City Transit routes operate with headways ranging from 25 to 60 minutes. Patrons are able to use Margate Inner-City Transit to make connections with three BCT routes $-18,31$, and 83 . BCT service at Margate Boulevard begins at 4:45 a.m.

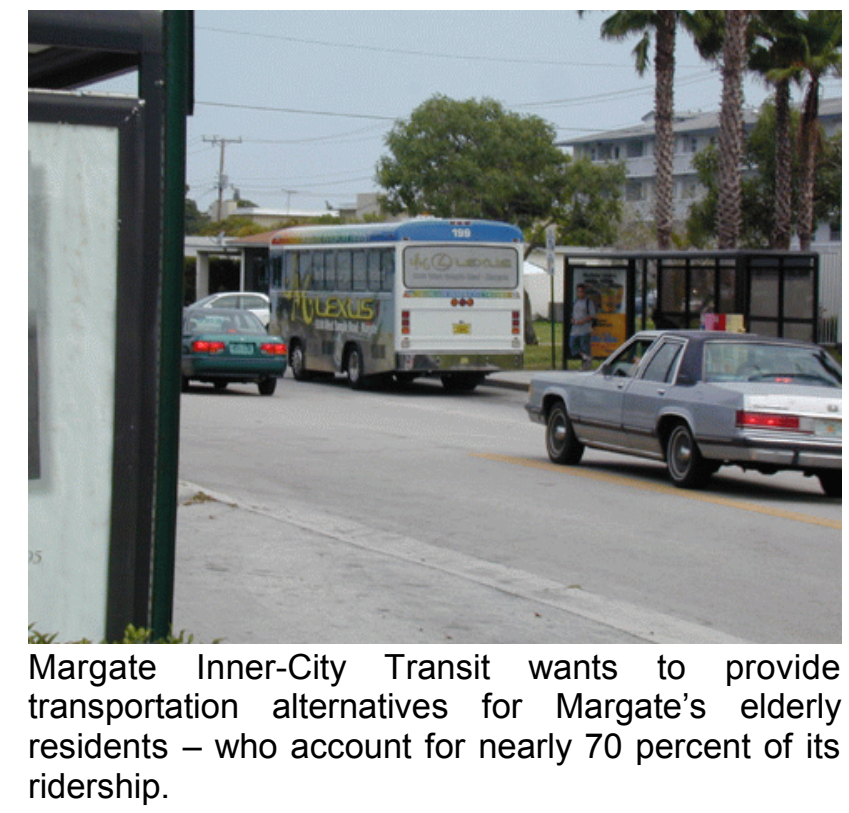

and continues until 10:55 p.m. with routes running every 15 to 30 minutes. There are no free or discounted transfers or coordinated fare mediums between BCT and MIT buses. 
Neighborhood Intermodal Transfer Facilities

Besides pedestrian, bicyclists, and transit passengers from BCT, other transportation services are provided at the Margate Terminal. The City of Coconut Creek Shuttle Service uses the Margate Terminal, and a private shuttle service that transports residents from the adult community of Wynmoor Village also uses the facility on a regular basis. The Wynmoor Village Shuttle transports residents to the Margate Terminal, which is near many community and senior activities. Coconut Creek originally operated one bus and recently began operating two additional buses throughout its community. One of its routes includes a layover at the Margate Terminal.

The Margate Terminal is simple and provides the basic necessities of a community bus stop. Besides a partially enclosed 4 by 8 foot shelter on each side of Park Drive, the Terminal consists of bench seating inside and outside of the shelter. Each side of the facility has newspaper vending machines and trash receptacles. The terminal also has signs identifying the transit systems (Margate Inner-City Transit and City of Coconut Creek Shuttle Service), as well as the routes. The facility includes a bicycle storage area and pay telephone.

The City of Margate initially became interested in having community bus service so that it could provide its elderly residents an alternative to driving. According to the 2000 Census, more than 31 percent of Margate's population is 55 years or older. Similarly, more than 30 percent of the households in the area surrounding the transit facility have persons age 65 or older. An indication of Margate's success in achieving its initial goal of providing alternatives for elderly citizens is that nearly 70 percent of Margate's ridership is seniors.

Besides the library and local government offices, the Margate Terminal is in proximity to the Northwest Senior Center and Community Center, a bank, and other communityoriented offices and businesses. The terminal is also near the Margate Police Department, to which its low level of criminal activity may be attributed. 


\section{Neighborhood Intermodal Transfer Facilities}

The participants of the Community Bus Service receive $\$ 20.00$ per annual revenue hour to assist with operating costs. The cost distribution for MIT in the 2001-2002 fiscal year was $\$ 266,260$ (13,313 annual revenue hours estimated). Those funds cover over half of the total system expenditures and local government support, fare revenues, and the bus and shelter advertising program provide the remaining financial support.

Costs of maintaining the Margate Terminal are minimal. The City of Margate replaced the shelters when it began participating in the Community Bus Service. The Margate Department of Parks and Recreation is responsible for disposing trash and maintaining the shelters. The simplicity of the Margate Terminal is one of the greatest factors in MIT being able to minimize costs. Thus far, MIT has been able to maintain its $\$ .25$ one-way fare.

There are advantages and disadvantages to the Margate Terminal and, while some of the disadvantages are a function of the small scale facility, most of the disadvantages can be eliminated through modified procedures. Table 2 lists features of the Margate Terminal that provide enhancements, as well as those things which could reduce intermodal interaction or affect satisfaction. 
Neighborhood Intermodal Transfer Facilities

Table 2: Advantages and Disadvantages of the Margate Terminal

\begin{tabular}{|l|l|}
\hline \multicolumn{1}{|c|}{ Advantages } & \multicolumn{1}{c|}{ Disadvantages } \\
\hline community scale & crosswalks need better demarcation \\
\hline $\begin{array}{l}\text { located near community centers and } \\
\text { activities }\end{array}$ & detailed route information not available \\
\hline located near senior activities & bicycle rack is partially hidden behind shelter \\
\hline accessible by several modes & connection with BCT not on-site \\
\hline inexpensive to maintain & $\begin{array}{l}\text { fare not standard between Margate and BCT } \\
\text { buses, nor are free transfers permissible }\end{array}$ \\
\hline
\end{tabular}

The Margate Terminal does not deploy fancy amenities; however, the facility and the service provided there illustrate the capabilities when space and funding are limited.

Washington Shores Superstop

The Central Florida Regional Transportation Authority, commonly known as Lynx, provides public transportation services in Orange, Seminole, and Osceola Counties. Lynx, several years ago, made a commitment to developing a public transportation system that is unique, dependable, entertaining, and recognizable. Arguably, Lynx has one of the most recognizable transit systems in the state of Florida, if not the country, with its bold and

Interesting Fact:

The standards used in the design of the Washington Shores Superstop came from the Central Florida Mobility Design Manual and the Customer Amenities Manual, which may be downloaded from www.golynx.com/whatshappening/pubs.

bright colored fleet. To compliment the vibrant fleet, Lynx has also committed to designing transit architecture "to be noticed." Lynx recognized that a passenger's first impression of the transportation system might be determined by the transit stop. One of their primary 
goals was to establish a style that is recognizable as "gateways into the Central Florida mobility system."

Lynx recognized the opportunities for impacts on land development of the area and facilitated a cooperative visioning process between the community, developers, planners, and others to encourage a balanced transportation system that included walking, biking, transit, and the automobile. In response, in 1994 Lynx developed the Central Florida Mobility Design Manual ${ }^{3}$ to "provide basic mobility design actions to be considered at the design and review level of individual projects." While the manual is available to serve as

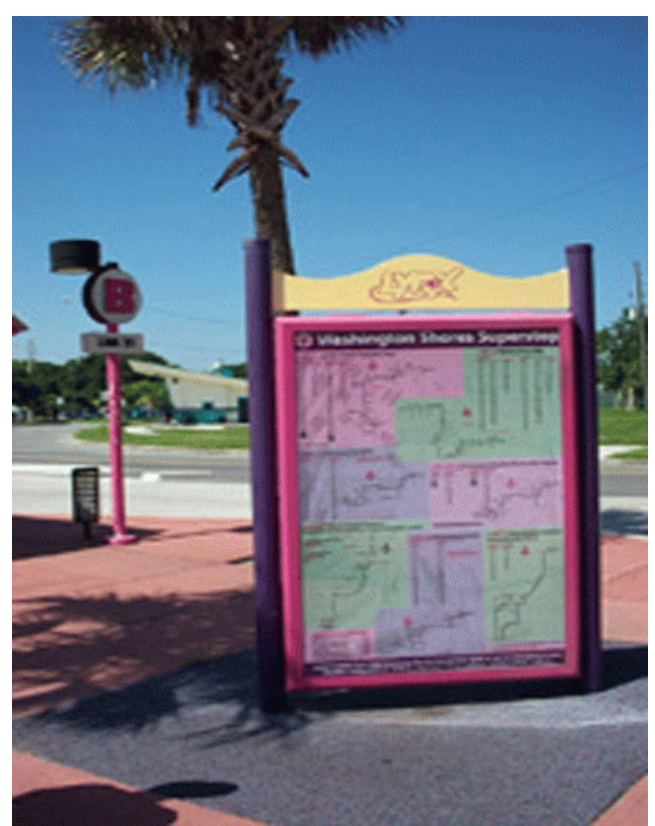

Washington Shore's routes are displayed in an information kiosk.

a guide to private developers, it also establishes guidelines used by Lynx for development of transit facilities. The impact of this manual on transit facility design can be seen all over the LYNX service area today. After the completion of the design manual, one of the first transit facilities upgraded using the new criteria was the Washington Shores Superstop.

${ }^{3}$ Glatting, Jackson, Kercher, Anglin, Lopez, Rinehart Inc. in association with Herbert-Halback and Associates. 1994 (Revised in 2000 by Lynx). Central Florida Mobility Design Manual. 
Washington Shores, located west of downtown Orlando, is a residential community of more than 6,000 people. The area is a low-to-moderate income residential community that has a relatively high concentration of transit-dependent population and pedestrian traffic. Washington Shores is a good example of how off-street neighborhood or community transit facilities can be designed to pay particular attention to pedestrian safety.

Prior to the December 1997 opening of the Washington Shores Superstop, Lynx used a wood and concrete facility on the same site, which was owned by the City of Orlando. For more than two years, Lynx worked with neighborhood leaders, residents, and city officials to develop an attractive facility design using the newly developed guidelines in the Central Florida Mobility Design Manual. The goal of the community and Lynx was to develop a functional facility that would complement the neighborhood.

The Washington Shores Superstop is an off-street facility that has eight sawtooth bus

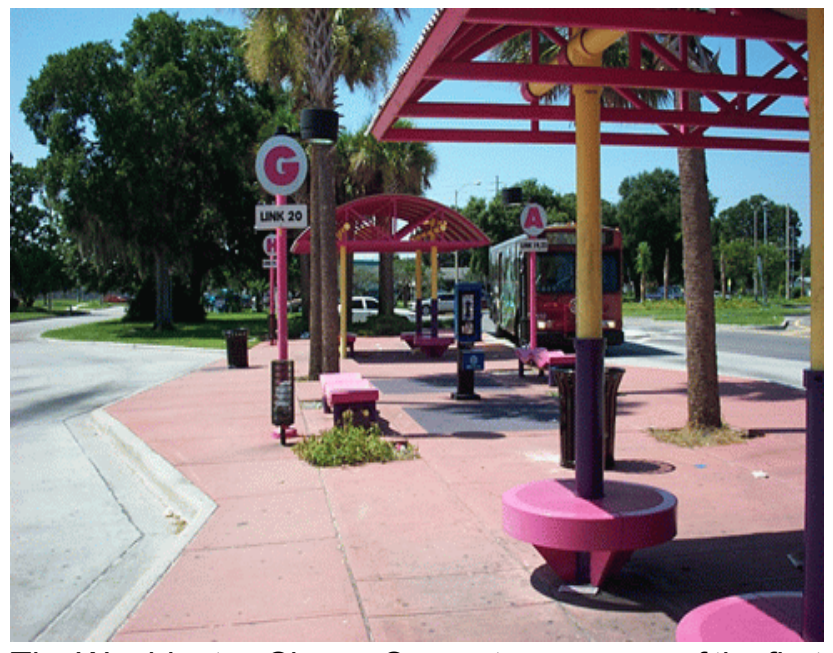

The Washington Shores Superstop was one of the first Lynx facilities upgraded using bold, colorful features.

bays, passenger shelters and seating, an information kiosk, secure bicycle storage, trash receptacles, and public telephones. Another task of the facility upgrade was to install faderesistant vinyl signs. The signs, which are posted throughout the facility, identify the "Link" 
Neighborhood Intermodal Transfer Facilities

or route numbers. In addition, the Superstop has effective lighting and attractive landscaping, including shrubs and over a dozen palm trees, which are planted in cutouts in the colored concrete paving. Besides providing an alternative to typical hardscape, the patterned paving creates visual differentiation from the passenger waiting area and the bus pull-in area.

Six Lynx routes currently arrive and depart from Washington Shores. Five of the "Links" are regular routes serving several service/tourism destinations on International Drive, as well as downtown Orlando. These routes operate daily at Washington Shores between 5:00 a.m. and 12:15 a.m. In addition to the regular routes, the Lynx 3-D or Downtown Disney Direct express service departs Washington Shores for the Downtown Disney West Side Transfer Center at 6:38 a.m. and departs Downtown Disney for Washington Shores at 5:15 p.m. Monday through Sunday and holidays. This service, which is utilized by employees of Disney who live in Washington Shores and surrounding communities, averages 26 passengers per trip.

Besides transit service, pedestrian and bicycle access are the other mobility modes supported at Washington Shores. When the City of Orlando reconstructed the roadways during the upgrade of the Superstop, flashing lights were installed over the crosswalks which lead from the Superstop into the neighborhood. The flashing signal serves as an additional warning for automobile drivers to acknowledge the presence of pedestrians. Consequently, there have been no reports of pedestrian incidents at the facility since it was upgraded. While there are no bicycle lockers at the facility, a leaning rail has served the purpose of a bicycle rack.

The area surrounding the Washington Shores Superstop has approximately 5,000 people. Over 50 percent of the community are youth or elderly (under 18 or over 65 years old). The area is characterized as low-to-moderate income and the median family income is well below that of the Orlando MSA. The area, which has a 9 percent housing vacancy rate, 
has over 2,000 housing units. Almost 50 percent of the housing is renter-occupied. ${ }^{4}$ There are several public or income-qualifying housing developments in the Washington Shores community.

Near the Washington Shores Superstop are several neighborhood businesses, such as community restaurants and convenience stores. Directly adjacent to the facility are a fish market, commercial strip development, and an automobile detailing service. Also located near the facility are a middle school, a neighborhood park and recreation center, and one of the community's largest churches which all contribute greatly to pedestrian traffic in the area.

It cost $\$ 249,000$ in 1993 to construct the Washington Shores Superstop. The land on which the facility sits is owned by the City of Orlando and is leased at no cost by Lynx. Amenities installed at the Superstop and throughout Lynx's newly-developed transit facilities, are usually more expensive than typical amenities; however, they generally have an additional life-span of 4-6 years. The upgrade of the Washington Shores facility was completed using block grant funds, as are all of Lynx's amenity projects. Maintenance is the responsibility of Lynx. While the facility infrastructure has not yet needed to be replaced, maintenance requirements include caring for the landscaping, disposing of trash, and updating route information.

The Washington Shores Superstop is one of Lynx's most used facilities. The demographic profile of residents surrounding this facility suggests that, perhaps, many would use the facility if it had not been redesigned in 1993. However, Lynx believes that image is important and that maintaining the transit stop is vital to that image. Table 3 identifies the advantages and disadvantages of the facility related to its intermodal interaction and

${ }^{4}$ U.S. Census Data, 2000. American Fact Finder. Accessed at http://factfinder.census.gov/servlet/BasicFactsServlet. 
Neighborhood Intermodal Transfer Facilities

customer utility. The key to the Washington Shores Superstop's effectiveness as an intermodal facility is its location and the enhancement of pedestrian amenities. Subsequent Superstop design and development in the Lynx service area have been improved to included water fountains, solar lighting, and more functional bicycle racks.

Table 3: Advantages and Disadvantages of the Washington Shores Superstop

\begin{tabular}{|l|l|}
\hline \multicolumn{1}{|c|}{ Advantages } & \multicolumn{1}{c|}{ Disadvantages } \\
\hline community scale & no bicycle racks \\
\hline amenities have longer life & amenities are more expensive \\
\hline $\begin{array}{l}\text { located near community activity centers, } \\
\text { such as park, church, and school. }\end{array}$ & $\begin{array}{l}\text { construction costs for off-street facility are } \\
\text { more expensive }\end{array}$ \\
\hline facility is identifiable & \\
\hline considerable amount of pedestrian traffic & \\
\hline
\end{tabular}

\section{Park and Ride Facilities}

Park and ride facilities are generally located in areas outside of the urban core where population densities can be too low to attract significant amounts of walk-on bus patronage. Instead, the park and ride functions as a local collection and distribution facility and generally presents an opportunity to reduce the converge of single-occupant vehicles from these outlying areas into major activity centers or downtown. ${ }^{5}$ These facilities may allow for carpool and vanpool staging, and may also serve as a stop on transit routes. Park and ride facilities are generally described as independent or shared. An independent lot is constructed solely for transportation purposes, usually by the transit agency or the state's Department of Transportation. A shared lot is usually a result of cooperation with a transportation entity (DOT or the transit agency) and a private development, such as a

\footnotetext{
${ }^{5}$ Sacramento Regional Transit District. September 1987. Design Guidelines for Bus and Light Rail Facilities.
} 
church. The private development allows for a designated portion of its lot to be used for park and ride patrons. The conditions of the shared lot partnerships vary, but often include compromises regarding lot maintenance, time and day usage stipulations, and rarely involve direct payments.

As transit needs outside of the urban core continue to grow, park and ride facilities are commonly finding a presence in suburban communities. Instead of developing full transit service in these areas, many transit agencies find that the most effective method of getting transit to these areas is to provide collector service to/from these areas to/from suburban communities or other transfer points in the existing service coverage area.

\section{G.I. Joe Tri-Met Park and Ride Facility}

Portland, Oregon has, perhaps, one of the most extensive park and ride systems in the nation. Tri-County Metropolitan District of Oregon (Tri-Met), which provides public transportation services in the Portland metropolitan area, owns over 20 park and ride lots. In addition, it has 39 shared-use park and ride lots. More important, Tri-Met has over 10,500 parking spaces available through both their owned and shared use lots and, on average, nearly 70 percent are occupied. 
Tri-Met recognizes that the lots provide access to the Tri-Met system for a large number

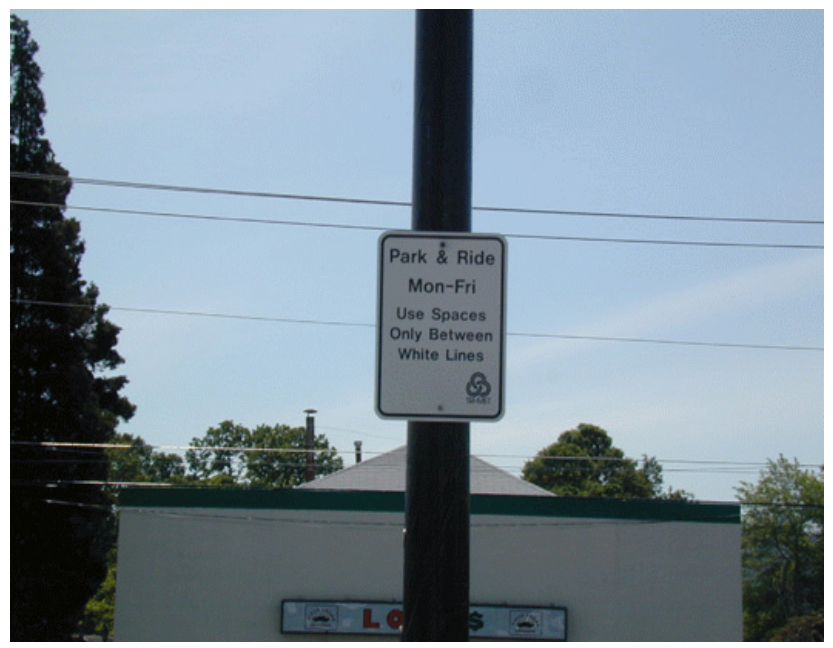

Tri-Met provides over 10,000 park and ride spaces through owned and shared parking lots.

of people in the metropolitan Portland area. Park and ride lots in the Portland area have been successful, in part, due to lack of inexpensive parking alternatives in the downtown area. Nearly half of the people in the region claimed to have used a park and ride facility, at least once, in $2000 .{ }^{6}$ While the popularity of the park and ride network demonstrates their usefulness, it has also caused overcrowding. The overcrowding has caused several negative effects, such as:

- $\quad$ Passengers are frustrated when they can't find a space.

- Spill-over parking onto streets and nearby lots generating complaints from neighbors.

- Potential passengers are turned away.

- $\quad$ Full lots also discourage off-peak or occasional use.

${ }^{6}$ Findings: Tri-Met Park and Ride Patron Survey. Conducted by Tri-Met in February 2000. 
In response to the success of the park and ride lots and resulting negative effects, Tri-Met organized an advisory committee composed of representatives from businesses, neighborhoods, local jurisdictions, and others with expertise in parking issues and a stake

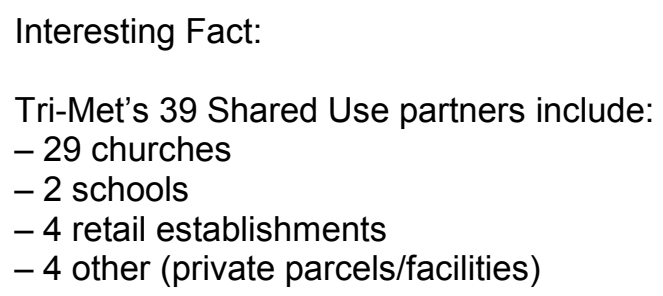

in the operation of park and ride facilities in the system. The committee was charged with the task of developing recommendations for dealing with overcrowding and other park and ride issues. In using the recommendations of the advisory committee, Tri-Met developed Tri-Met's Park and Ride Policy. According to the policy, Tri-Met is dedicated to securing and expanding the park and ride facilities in the Portland metropolitan region. When the owners of a southeast shared park and ride lot decided that they would severely limit the availability of spaces and impose a higher fee to park and ride users, Tri-Met responded by finding a nearby alternative for the users. The result was the shared use arrangement with the G.I. Joe Sports and Auto Center in the Milwaukie community.

In late 2000, Tri-Met established the G.I. Joe Park and Ride facility in a community southeast of the Portland Central Business District (CBD). There are 50 spaces allocated to park and ride users on weekdays. The neighboring lot that closed had 317 spaces and was usually filled to capacity. Understandably, the G.I. Joe Park and Ride facility has had 100 percent occupancy from the start.

The park and ride facility is located in the Milwaukie community. The population of the area surrounding the facility is nearly 5,000. It is a family-oriented community in which 26 percent of the population are under the age of 18 and nearly $3 / 4$ of the households are 
owner-occupied. According to the 1990 census, most working people in this community commute to the Portland CBD. While the 2000 Census data regarding commute has not been released, all indications are that this trend still stands, as park and ride usage continues to rise.

Nearly any of Tri-Met's park and ride lots could have served as an effective example, but the G.I. Joe Park and Ride lot exemplifies a successful partnership, neighborhood scale, and customer convenience. Tri-Met establishes with its park and ride lot owners, a

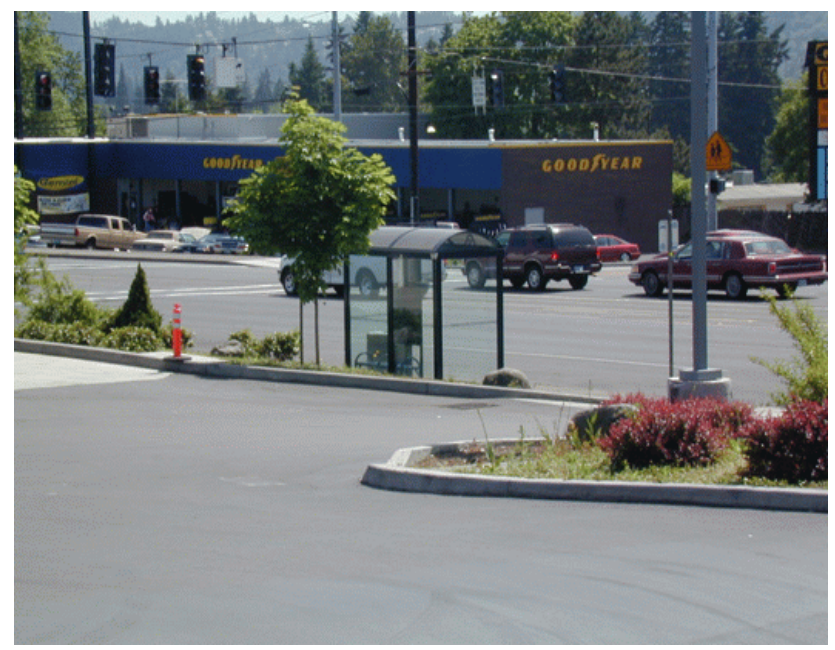

The passenger shelter for northbound buses is a couple of hundred feet from the park and ride lot. Passengers must cross McLoughlin Boulevard for the southbound buses.

cooperative relationship that outlines each party's responsibilities. This, according to Young Park of Tri-Met, has facilitated the successful partnership.

The arrangement with G.I. Joe Sports and Auto Center was initiated when Tri-Met realized that the shared lot arrangement at the neighboring theater was ending. In exchange for the 50 designated parking spaces, Tri-Met agreed to put up additional parking lot lighting, restripe and reseal the park and ride section of the parking lot, and share responsibility for street sweeping. Tri-Met also put up a sign which has become standard at its park and ride 
facilities. The sign acknowledges the presence of a Tri-Met park and ride facility and also pays recognition to the partner or lot owner.

Most, if not all, of the G.I. Joe Park and Ride lot users have weekday commutes from Milwaukie to the Portland CBD. Express service to downtown Portland is provided through Tri-Met bus route 99x. Adjacent to the G.I. Joe Park and Ride is a sheltered Tri-Met bus stop. A similar bus stop for routes in the opposite direction is located on the other side of

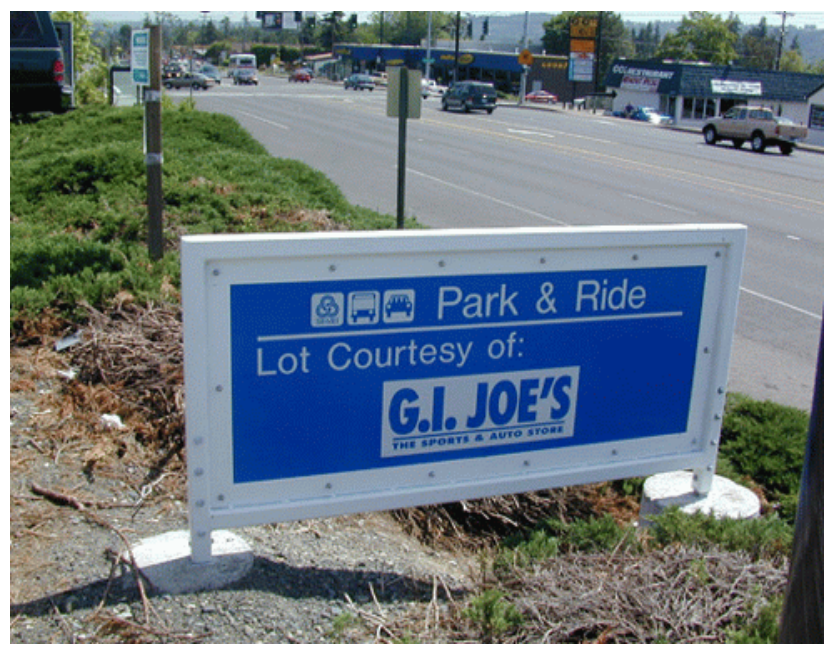

Tri-Met installs similar signage at all shared use park and ride lots. The signs acknowledge the partners in the park and ride venture.

McLoughlin Boulevard, which is a five-lane road and also has a bus pull-out lane. Both of the bus stops are on the far side of a traffic signal that also has pedestrian crossing signals. Besides the express route, Route number 33 also stops at the G.I. Joe Park and Ride lot. Tri-Met saw a 25 percent increase in bus service ridership on both routes when the park and ride was established.

As mentioned earlier, in exchange for the use of 50 parking spaces, Tri-Met agreed to install additional parking lot lighting, restripe and reseal the park and ride area of the parking lot, install signage, and split the street sweeping costs. The G.I. Joe Sports and Auto Center agreed to be responsible for any other maintenance activities and associated 
Neighborhood Intermodal Transfer Facilities

costs. Specifically, Tri-Met installed five additional lights similar to those already on the lot for $\$ 22,000$ and entered into an annual contract for half the cost of lot sweeping at $\$ 300$ per quarter or $\$ 1,200$ per year. Tri-Met's share of the lot sweeping costs were one-half of the total costs, which suggests that the total annual cost for sweeping the lot was $\$ 2,400$. Tri-Met incurred costs of $\$ 4,000$ to restripe and reseal the lot. Total facility costs were approximately $\$ 30,000$. The contract with G.I. Joe is for one year, after which either party can discontinue participation. Besides lot sweeping, there will be no additional costs in the next year, if the contract is continued.

Table 4: Advantages and Disadvantages of the G.I. Joe Park and Ride Facility

\begin{tabular}{|l|l|}
\hline \multicolumn{1}{|c|}{ Advantages } & \multicolumn{1}{c|}{ Disadvantages } \\
\hline $\begin{array}{l}\text { provides alternatives in an automobile- } \\
\text { dominated community }\end{array}$ & $\begin{array}{l}\text { users may have to cross multi-lane road to } \\
\text { reach buses }\end{array}$ \\
\hline minimal annual costs & lot size is relatively small \\
\hline spaces are 100 percent-occupied & lot becomes full early \\
\hline close to residential areas & shared lot contract renewal is uncertain \\
\hline $\begin{array}{l}\text { express service/park and ride use popular in } \\
\text { Portland metropolitan area }\end{array}$ & \\
\hline
\end{tabular}

In general, park and ride lots have been extremely effective in the Portland, Oregon metropolitan area, in part, due to the parking enforcement initiatives in the CBD and the commitment of Tri-Met to establishing a park and ride network. The G.I. Joe Park and Ride Lot demonstrates a successful and inexpensive option that transit agencies may employ in areas where extensive transit service may not be a viable alternative.

\section{Transit Centers}

As communities continue to expand beyond the urban core, the need for transit in those areas intensifies. Small park and ride lots with complementary express service may no 
Neighborhood Intermodal Transfer Facilities

longer be sufficient. Eventually, the need for additional routes and convergence or layover locations in those areas may lead to a decision to construct a transit center. The transit center introduces a dedicated transportation hub that is identifiable to the community as a home for transportation alternatives.

Actually, transit systems may vary in their definitions of a transit center. However, the two cases that are presented below are independent transit facilities having other activities that are secondary only to transit activities. The transit center is a way to provide transit services to a community while also meeting other needs, such as community meeting space.

\section{Fisher's Landing}

In Vancouver-Clark County, C-Tran is the public transportation agency. Vancouver is across the Columbia River, north of Portland, Oregon and their communities are similar in terms of public support and use of public transportation. However, C-Tran recently experienced drastic cuts in their funding levels when 40 percent of their funding mechanism was repealed by the state legislature. C-Tran was operating at 1991 funding and 1996 ridership levels as a result of the funding cuts. In response, C-Tran cut service by 30 percent, primarily by cutting late night transit service.

Just as funding was cut, C-Tran was beginning the construction on a new transit center in southeast Vancouver. There was discussion of scrapping plans for the facility and relying on existing facilities, which had already been determined to be inadequate. C-Tran staff believed that Fisher's Landing, although not yet constructed, would have more utility to the area than the existing transit center. The existing Evergreen Transit Center, was constructed in 1990 to serve the growing number of commuters to downtown Vancouver and downtown Portland. After a couple of years, however, C-Tran recognized that the facility was outgrown and had become less effective. Fisher's Landing was to be a larger 
site that would better serve the east county area and, in particular, the Camas/Washougal residents. After careful analysis and much public scrutiny, C-Tran determined that Fisher's Landing Transit Center would indeed open and that services at the Evergreen facility (except for the park and ride lot and limited commuter routes) would be terminated.

Fisher's Landing Transit Center is an appropriate illustration of balancing the transportation needs of a community with its desire to minimize the negative image associated with a facility larger than that of a local bus stop. C-Tran also can be credited for developing a facility that is capable of drawing non-transit users through secondary activities on the site. This creates an opportunity to generate more ridership and support for transit activities. The size of the facility is mostly a factor for the park and ride needs of this suburban community, as well as demand and frequency levels.

The site selection process involved performing an alternatives analysis on seven potential sites and eventually performing a cost-benefits analysis on two of those sites. This resulted in the selection of a site just north of the Columbia River and east of Interstate 205. The community surrounding the facility is automobile dominated, as are most communities away from the urban core. However, there are a considerable number of people that use transit to commute to and from the central business districts of Portland and Vancouver. The community was informed of C-Tran's plan to develop a transit center and expressed resistance to those plans. In an effort to hear and respond to the community's concerns, C-Tran held several charettes (both internal and external) to provide transit staff and the public an opportunity to participate in the planning and design of the facility.

Specifically, C-Tran organized focus groups made up of the general public, placing emphasis on having diverse interests represented. In addition, they conducted public meetings during the day and evening. Interestingly, C-Tran recognized that many of the area's residents worked in downtown Portland, so it organized meetings in downtown 
Portland during the lunch hour. The community meetings and attempts to gain public involvement yielded C-Tran useful comments ranging from light and plant selection to preferred circulation patterns.

Subsequently, a design committee was also formed. While all were invited to participate, this group consisted mainly of advocates and those with design interests. At the design committee meetings, volatile issues, such as noise and light pollution were addressed along with careful consideration of associated, non-transit activities. Through this process the community expressed a desire for several secondary activities, such as a community college branch; however, a compromise was reached and a community center was

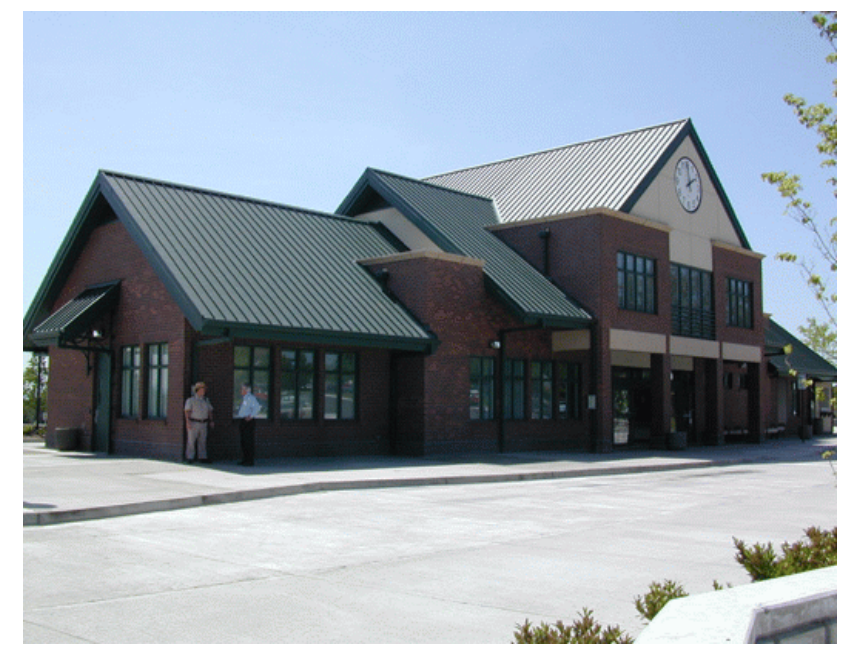

Fisher's Landing was designed using input from community focus groups and a design committee.

planned instead.

The selected site is near the Columbia River and was consequently designated as Category II wetlands, which required stringent stormwater mitigation. Included in the project are over three acres of stormwater retention facilities. Interestingly, C-Tran partnered with local schools to utilize the area for biology projects and learning exercises. 
Fisher's Landing Transit Center opened in July 2000. C-Tran and the Clark County community are very proud of its newest transit center. The facility, as a result of the efforts of the community design committee and the staff of C-Tran, exhibits customer-friendly amenities. The 23-acre site consists of a two-story structure, 560-vehicle park and ride lot, enclosed bicycle lockers, and four acres of reserve area in case capacity is reached. The building at Fisher's Landing houses a C-Tran Customer Service Office, which is open on weekdays from 7:00 a.m. to 7:00 p.m. Transit patrons may purchase bus tickets and passes, as well as get route and system information. The building also has a break room

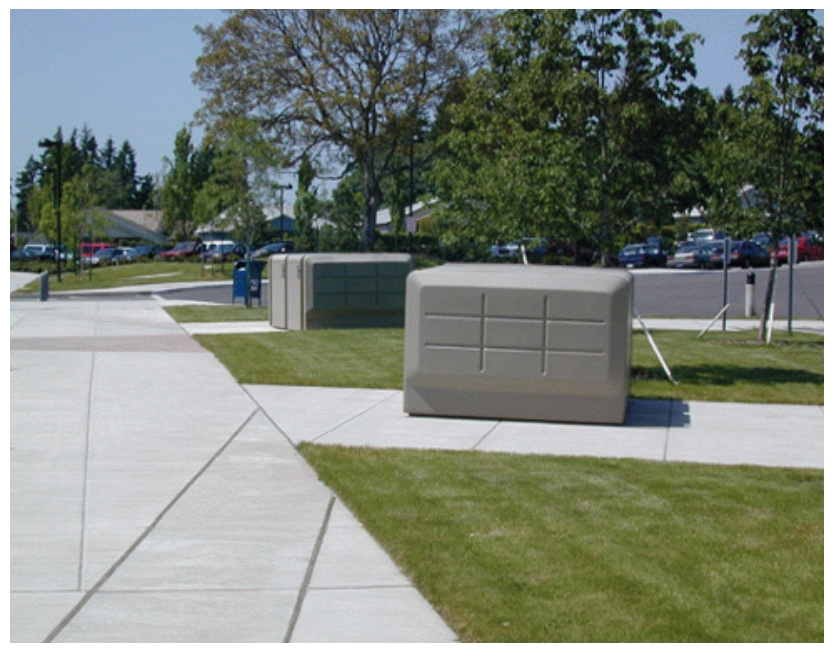

Users of Fisher's Landing can leave their bicycles in covered bicycle storage lockers.

for bus operators to use during layovers. The transit center was designed to incorporate mixed-uses. Besides the transit operations activities, Fisher's Landing Transit Center also has office space for shared uses, which currently include a community-oriented police substation. On the second floor of the facility is a meeting room, used by the community for neighborhood meetings. The community room is extremely popular and much needed, which is evident by its booked-status months in advance. Also, in the lobby of the transit center is a public display area for community notices and acknowledgments. The public area is frequently used to display local art and school exhibitions. 
The Fisher's Landing Transit Center has full-time security from 5:30 a.m. until 10:00 p.m. on weekdays (hours of transit service), as is the case at all C-Tran transit centers. This is to discourage car vandalism and thefts. Landscaping at the facility mainly consists of natural vegetative swales and is maintained by C-Tran. The building splits the parking lot, so that park and ride users do not have far to walk from either parking area. In addition, a circular drive is available to vehicles dropping off passengers ("kiss and ride"). This drive is located so that these passengers do not have to cross the parking lot or walk far to board their buses. The walkways from the parking lots to the bus staging areas are defined and

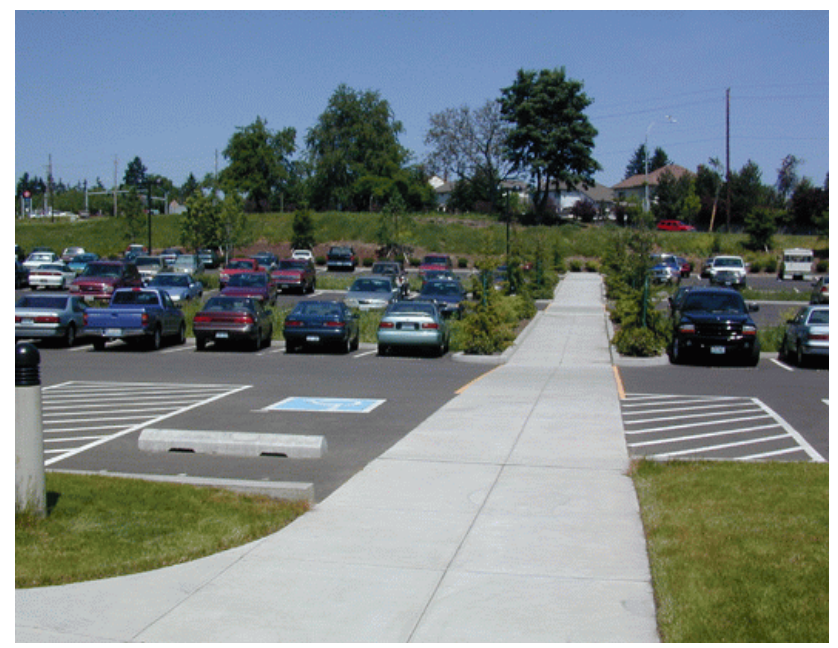

Wide, inviting sidewalks that lead to the buses are placed throughout the parking lot for pedestrian safety.

require very limited interaction between pedestrians and vehicles. In the mornings, a coffee vendor operates at the transit center and patrons are able to purchase newspapers.

There are currently seven routes operating out of Fisher's Landing. One of the routes is an express route that runs to downtown Vancouver and downtown Portland. There are also two other commuter express routes to downtown Portland and four regular C-Tran routes. There are four bicycle storage lockers which accommodate two bicycles each (for a total of eight). Use of these lockers requires a lease agreement. This procedure was 
established to avoid inappropriate use of the bike storage bins. All of the bike lockers are currently occupied.

Another interesting aspect of this facility is the bus-only merge lanes onto the nearby interstate. C-Tran, after coordination with the Washington Department of Transportation, constructed a bus-only merge lane leaving the facility. The lane allows buses leaving the facility to merge onto Interstate 205 using a bus-only lane, creating a priority status and limiting the interaction of bus and automobiles at an otherwise congested intersection.

Fisher's Landing is located adjacent to a subdivision in Clark County, Washington. The homes in the subdivision range in price from $\$ 250,000$ and up. The area surrounding the facility has a population of nearly 5,000 and over 2,200 households. The area has a 95 percent occupancy rate and 73 percent of the homes are owner-occupied. During the

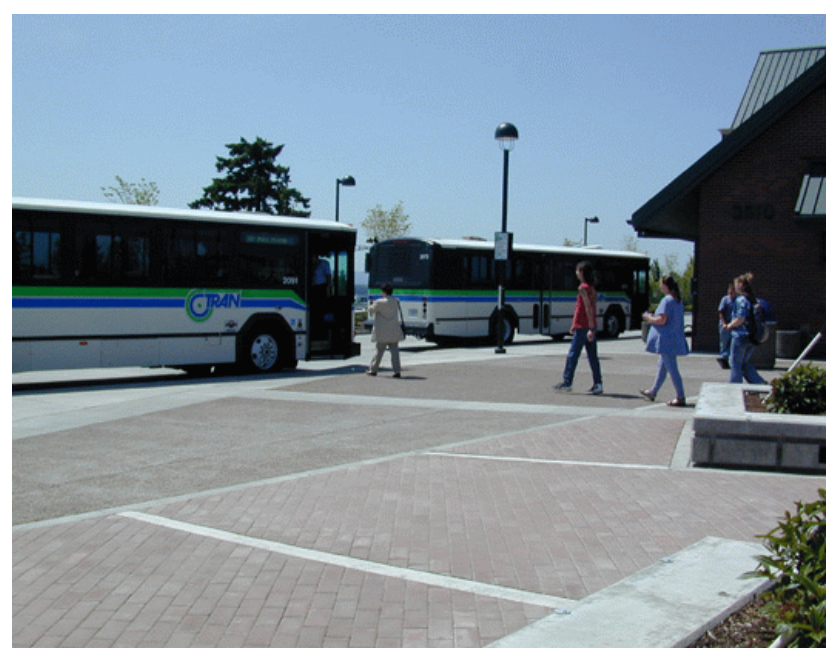

C-Tran offers express service from downtown Portland and downtown Vancouver from the Fisher's Landing Transit Center.

planning and design processes, several neighboring parcels were purchased and developed. This activity prompted many who had opposed the transit center to cease the resistance, as reality that "big box" development could be a viable alternative. 
Neighborhood Intermodal Transfer Facilities

The Fisher's Landing Transit Center was expensive to build. The land and stormwater mitigation alone cost 5 million dollars. The construction of the facility cost another 4.5 million dollars, for a total cost of nearly 10 million dollars. Besides the two-story building, some of the greatest costs were signalization and road improvements. While the features of the facility may be more costly than that which most agencies are comfortable, several concepts used at Fisher's Landing, including the use of vegetation and layout to create a safer environment, may be duplicated less expensively.

Table 5: Advantages and Disadvantages of the Fisher's Landing Transit Center

\begin{tabular}{|l|l|}
\hline \multicolumn{1}{|c|}{ Advantages } & \multicolumn{1}{c|}{ Disadvantages } \\
\hline accommodates mixed uses & large land requirements \\
\hline within walking distances of many residents & expensive construction costs \\
\hline activities for transit and non-transit users & expensive operating costs \\
\hline facility is identifiable & auto-dominated community \\
\hline
\end{tabular}

C-Tran probably could have built a cheaper transit center than Fisher's Landing. It could have reduced its land requirements by constructing a few shelters and bus bays and modified the layout of its park and ride lot to meet the basic needs of the east county commuters. However, C-Tran chose to develop a facility that had the ability to draw its community into the facility and placed value on safety and environmental issues. C-Tran is convinced that Fisher's Landing will have a role in the community for years to come, because as long as commuters need to cross the Columbia River into Oregon and the costs of driving and parking in the Portland CBD continues to rise, there will be a need for commuter-express service and park and ride lots at Fisher's Landing. Furthermore, the secondary activities at the facility are popular and the community has bought into Fisher's Landing, even after having reservations at the outset.

Columbia Station 
A few hundred miles away from Fisher's Landing in Vancouver is another transit center along the Columbia River. Columbia Station is in Wenatchee, located in the center of the State of Washington. Wenatchee is fairly rural and the urban area has a population of 50,000 . Unlike Fisher's Landing, which was constructed to serve residents of a suburban community, the Columbia Station was constructed in the downtown area of town and serves as a main transportation hub for the system.

Interesting Fact:

In recognition of excellence in downtown revitalization, the Washington State Community Trade and Economic Development Association awarded Link Transit the 1998 Outstanding Design Project Award for Columbia Station.

Link Transit is the public transportation agency for the designated Public Transportation Benefit Area (PTBA), which includes areas of Chelan and Douglas Counties. Link Transit is a relatively new system, with start up in December 1991. The Columbia Station opened in July 1997 and would later be recognized nationally for its outstanding design.

The entire transit center development included the construction of an off-street bus transfer center, pedestrian streetscape connections, pedestrian/bicycle access bridge to connect an inter-community bike and walking trail, and passenger rail and inter-city bus depots. In addition, the transit center includes a 60-space park and ride lot. Columbia Station was selected as a case study because it most exemplified the concept of intermodalism, including transit, private shuttle, taxi, bus, train, bicycle, pedestrian, and park and ride. Columbia Station was neither cheap to build nor on a neighborhood scale; however, the intermodal components, as well as the commitment of the new transit system and its community were factors considered when this facility was selected to be featured in this report. 
In 1992, shortly after Link initiated service in Chelan-Douglas Counties, an intermodal transportation facility feasibility study was completed. A site selection process followed yielding a "short-list" of three sites that were considered after an environmental assessment review. This site was selected, in part, due to its proximity to both the rail line and the bicycle/pedestrian inter-community network.

The Columbia Station consists of an off-street transit layover area with eight bus bays. The buses enter the facility through one of two streets and exit from the other (depending on which direction the route is traveling). The bus area is connected to Columbia Street, Wenatchee Avenue, and the customer service center and office complex by several welldelineated walkways. There are currently eleven regular routes served at Columbia Station. In addition, two LinkPlus (the complementary paratransit service) buses also serve the station. Of Link Transit's 14 fixed-routes, eleven lay over at the Columbia Station.

There are also bike lockers on site. The bike racks on the buses and the bike lockers at Columbia Station are used consistently in the spring, summer, and fall. In the winter, however, the bike racks are interchanged with ski racks on those buses serving the ski routes. This, too, is a popular service.

The transit center also includes a three-story building which houses the Link Guest Relations Office and other activities, most of which are non-transit related. The first floor of the facility is reserved for guest activities, including a waiting area, restrooms, and pay phones. Customers may get personal assistance from transit representatives during the week from 6:00 a.m. until 6:00 p.m. 
Initially, the transit center building was proposed to serve as the main location for Link activities, including administrative services. Link Transit decided to keep most administrative functions at its existing facility and to create an office environment for other organizations. The building has become home to several businesses and community organizations, such as the Wenatchee Valley Chamber of Commerce, the Small Business Development Council, the Mission Ridge Public Development Authority, and the Welfare to Work Resource Coordinator and Mentorship Program. These organizations make up the Columbia Business Information Center.

The Columbia Station is also linked to the park development and pedestrian system that surrounds the Columbia River. The station was strategically placed near trails to enhance the inter-community bicycle and pedestrian system that exists in Wenatchee. Wenatchee

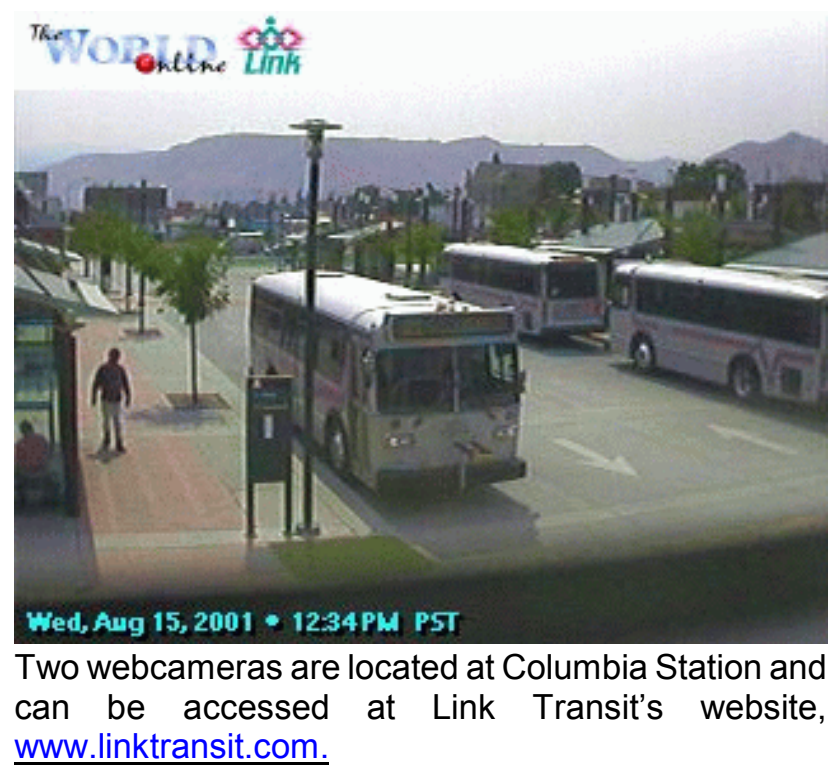

has both a pedestrian and bicycle plan. 
Neighborhood Intermodal Transfer Facilities

In addition to the office building/transit customer service center and bicycle/pedestrian facilities, Columbia Station has 60 park and ride spaces for transit users, carpoolers, and vanpoolers. Link estimates that the park and ride lot is $2 / 3$ full during the workday. Adjacent to the Customer Service Center is a Trailways bus staging area. The inter-city transit service has four buses departing from Wenatchee daily. Amtrak passenger rail also has a platform at the Transit Center. The Amtrak train depot, which opened in June 1998, consists of a 400-foot accessible boarding platform, three shelters, and an additional 57space parking lot. Two Amtrak trains depart from the station each day.

Table 6: Advantages and Disadvantages of Columbia Intermodal Station

\begin{tabular}{|l|l|}
\hline \multicolumn{1}{|c|}{ Advantages } & \multicolumn{1}{c|}{ Disadvantages } \\
\hline $\begin{array}{l}\text { serves all transportation modes in the } \\
\text { Wenatchee area }\end{array}$ & larger than neighborhood scale \\
\hline accommodates mixed uses & expensive construction costs \\
\hline $\begin{array}{l}\text { able to generate income from facility tenants } \\
\text { to support operating expenses }\end{array}$ & expensive operating costs \\
\hline
\end{tabular}

The Columbia Station, much like Fisher's Landing in Vancouver, was expensive to construct. The land and construction of the facility cost approximately nine million dollars, with the major funding source being federal, followed by local cash reserve. The most expensive aspect of the project was the three-story building, followed by the off-street transit staging area. The project received 80 percent of the necessary funding from the Federal ISTEA Enhancement program.

Having a relatively small transit system did not stop Link Transit from planning and completing an intermodal transit center. Link Transit began planning this endeavor within its first year of operation. Every possible mode of travel in the Wenatchee area is served by this station, contained within five acres. While the ability to organize the modes under 
Neighborhood Intermodal Transfer Facilities

one center is impressive, the location of the transit center provided an opportunity for many non-transit related community services to coexist, enhancing livability for many in the area.

\section{Rail Stations}

A neighborhood rail station usually serves intermediate points along a light, heavy, or commuter rail corridor. The rail facility often exists in conjunction with other transportation modes, such as bus and park and ride. Recent trends have also included transit-oriented development which include office, residential, and/or retail development. Boardings and alightings at rail facilities tend to be more intense than at other transit facilities, since rail corridors generally serve as trunk lines through areas of greater density.

\section{Wellston MetroLink Station}

When is a rail station more than a rail station? When it becomes the catalyst for over $\$ 35$ million in public and private investment in a community that is plagued by crime, high rates of unemployment, abandoned buildings, and misplaced dreams. In 1993, the Bi-State Development Agency (BSDA), which serves as the transit operator in the metropolitan St. Louis area, opened the St. Louis MetroLink light-rail system. The original 18-mile MetroLink line ran west to east from Lambert International Airport to the Fifth and Missouri Streets Station in East St. Louis. The line has since been expanded further west to Southwestern Illinois College in Belleville, Missouri. While the MetroLink corridor connects many of St. Louis area's major destinations, such as Union Station, Busch Stadium (home of the Cardinals), and the famous Gateway Arch, the light rail system also serves areas of St. Louis County that are deteriorated and neglected. 
According to the St. Louis County Economic Council, the greatest contributor to revitalization of one of those neglected areas was when BSDA constructed a MetroLink rail station through it. The Wellston community is part of an inner-city area that contains 50 percent of the region's poverty-level population. ${ }^{7}$ The community has had more than its share of adversity. The housing vacancy rate is 20 percent, 16 percent greater than the vacancy rate in St. Louis County. The unemployment rate is 2.5 times greater than the national average. Low graduation rates plague the area. Finally, a violent murder of a

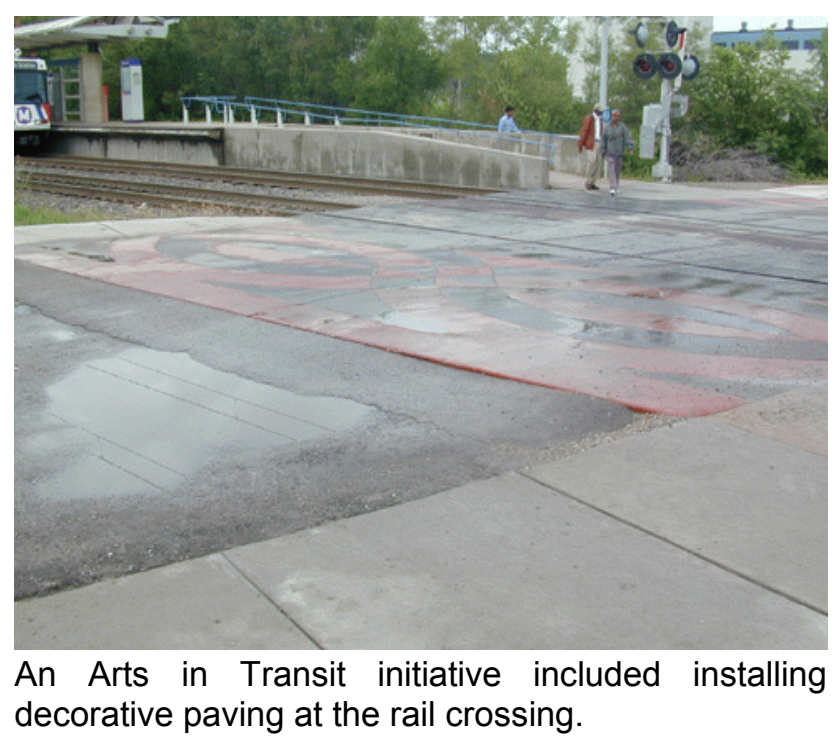

youngster in 1991 was the proverbial "straw that broke the camel's back" for many residents of the area.

In 1995, the Urban Land Institute (ULI) formed an advisory panel to study three MetroLink station areas of which Wellston was one. From the study came several recommendations. The panel's recommendation emphasized revitalizing Wellston and specifically focused on pedestrian improvements, MetroLink design enhancements, and the development of a

${ }^{7}$ Alschuler, Karen B. and Sarah B. Smith. April 1997. Transit and Development: St. Louis MetroLink. Urban Land, 56 (4): 38-41, 77-78. 
technology park and education center. From the presence of the MetroLink station and the resulting increase in mobility for the residents, as well as from the recommendations of the ULI Advisory Panel, the Wellston community has an opportunity to experience rebirth.

The Wellston MetroLink Facility was selected as a case example to demonstrate how

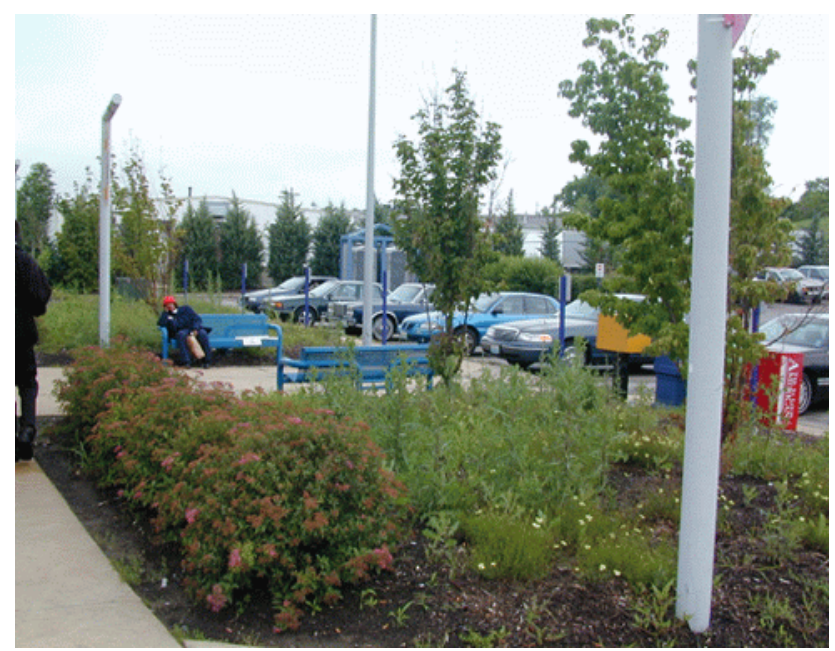

A Livable Cities Grant was used by BSDA to enhance Wellston's MetroLink Station with landscaping.

neighborhood transit can positively impact a community. Through a deliberate community involvement process and great detail to design and amenities, the Wellston Station has spawned a vision of improved mobility for the transit-dependent, unparalleled training and employment opportunities, and increased home-ownership.

In 1991, BSDA began the site selection process for the MetroLink light rail stations along the proposed rail corridor. The process had heavy community involvement, and provided several opportunities for the communities along the corridor to participate in charettes and informative meetings.

Even after Wellston was selected and constructed, there were several other opportunities for public input. Of particular interest was the Neighborhood Advisory Committee established by BSDA to work with the Arts in Transit Program to assure that community 
interests and history were reflected in the design of Wellston. Using local funds and a Livable Communities grant, BSDA and its capable partners in this venture initiated an extensive community outreach program to identify priority projects in the Wellston area. Arts in Transit and BSDA working in conjunction with the East-West Gateway Coordinating Council, the Economic Council of St. Louis County, and the City of Wellston involved community residents in choosing a public art display to be located on the station grounds. In addition, new distinctive signage was installed and street improvements along Plymouth Avenue were completed. Street improvements included the installation of a decorative brick design on both sides of the light rail track to offer uniqueness to the intersection and the station.

The Wellston Station consists of eastbound and westbound platforms, separated by Plymouth Avenue. Although each platform is elevated, they are completely accessible for persons with disabilities. Each platform also has a canopy shelter providing limited protection from inclement weather. On the platforms, transit patrons can find route information and purchase rail tickets from self-serve ticket vending machines. The ticket vending machines are equipped with audio features and Braille to assist customers with

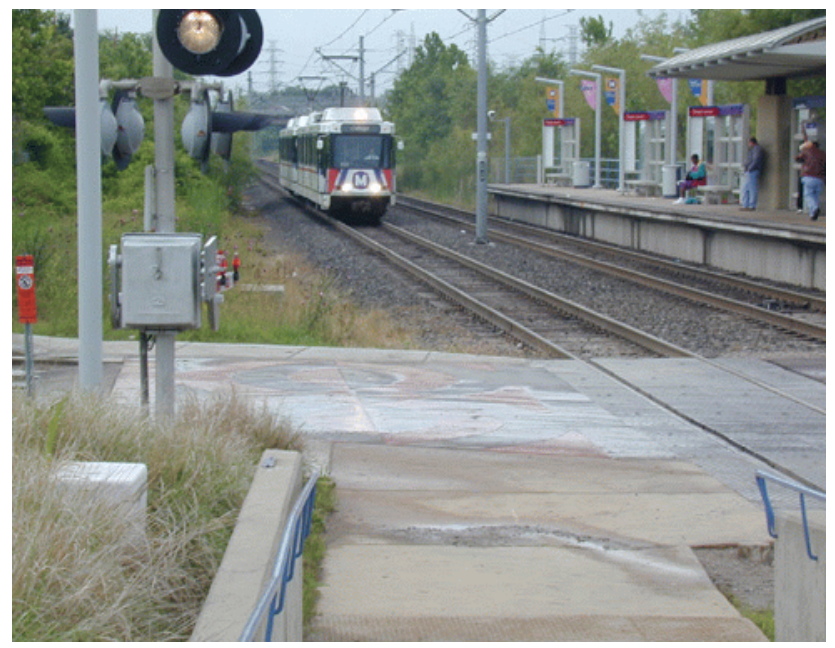

The rail platform is elevated, but accessible to all by ramp.

visual impairments. In addition, each platform has lighting and limited seating. 
MetroLink operates seven days a week. During the week, rail service at the Wellston Station operates between 4:59 a.m. and 1:04 a.m., with peak hour service every 7 to 8 minutes, off-peak service at 10-minute intervals, and evening service every 15 to 20 minutes.

North of the westbound platform is a park and ride lot with "kiss and ride" and on-street bus staging areas. The park and ride lot has a 75-car capacity and is typically 60 percent occupied on weekdays. The park and ride lot, just as the MetroLink platforms, are well-lit.

Three regular bus routes and one limited bus route run from the bus staging area of the Wellston Station. The regular routes provide service seven days per week at varying intervals, depending on whether it is during peak, off-peak, or evening hours. The express route is a truncated version of one of the regular routes and operates during peak hours on weekdays.

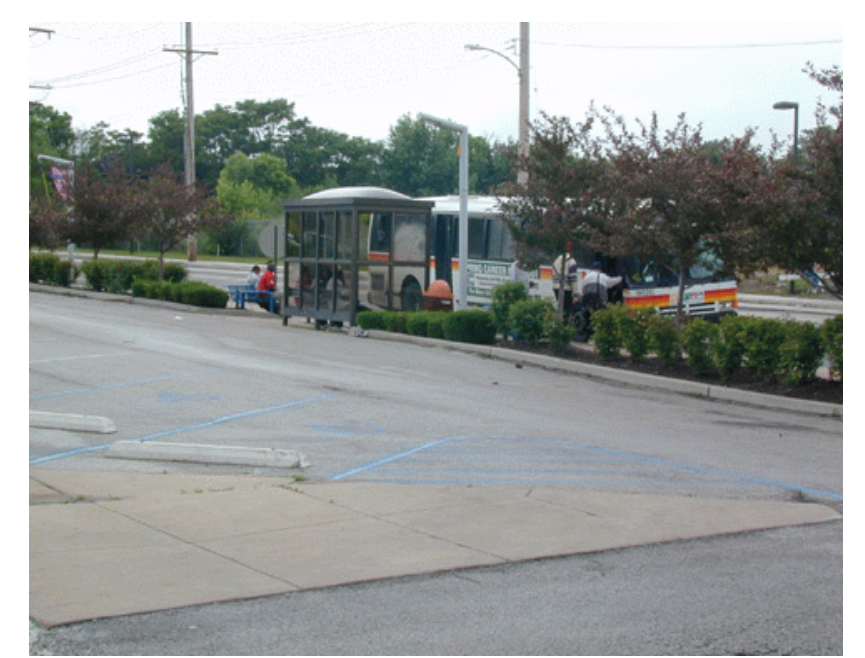

The MetroBus shelters are adjacent to the Wellston park and ride lot. 
Patrons board buses at an on-street area along Plymouth Avenue. The bus stop has two typical bus shelters (enclosed on three sides) on each side of Plymouth Avenue. Route information is not posted within or near the shelters. However, signs with route numbers are posted near the shelters.

Since many of the Wellston residents have no access to automobiles, pedestrian traffic in the area is quite high. As the services at the MET Center continue to grow and as other activities in the area are developed, such as the child care center and neighborhood park,

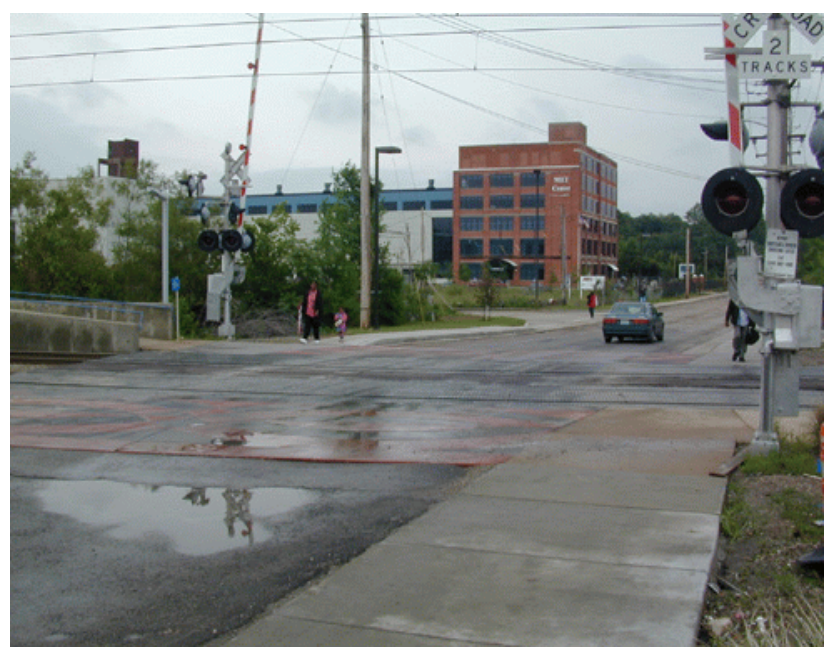

The Met Center, seen in the background, is a training center and business incubator.

foot traffic will also continue to grow. BSDA recently installed new sidewalks and curbs along Plymouth Avenue to create a safer and more attractive environment. 
The 25 acres surrounding the Wellston Station are still a "work in progress." As a result of the ULI Advisory Panel recommendations, the Wellston Technology Park is being

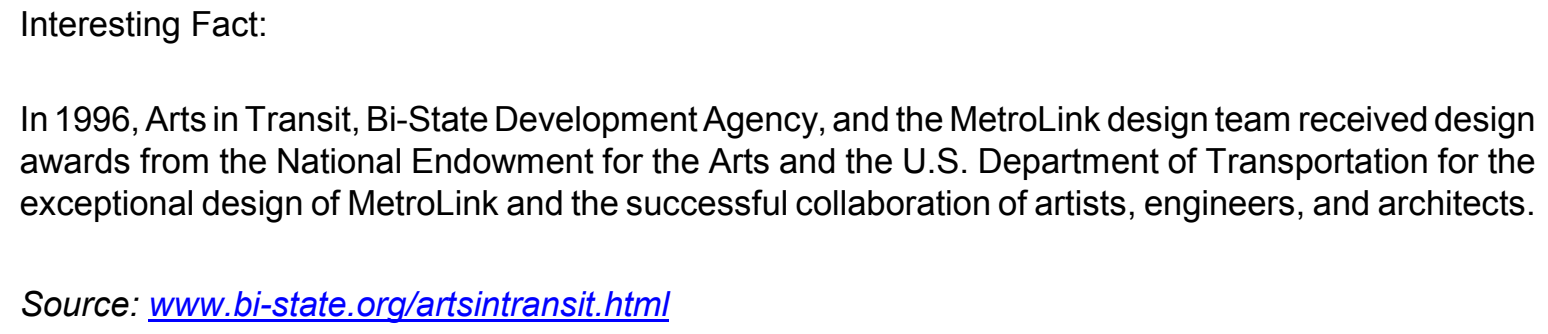

developed. This business/industry park will consist of an education and training center, over 800,000 square feet of light industrial space, 20,000 square feet of retail space, and over 100 new homes located on infill lots throughout the community. While several public and private partners are involved in the redevelopment of the area, the St. Louis County Economic Council has been at the forefront of activities. One of the first accomplishments has been the conversion of the formerly abandoned Wagner Electric into the Metropolitan Employment and Training Center (MET Center), which is a training center and business incubator. Although Wagner Electric appeared to be nothing more than a crumbling building and community eyesore, the Economic Council saw an opportunity to offer the community a benefit that, coupled with the promise of improved mobility with the MetroLink station, would vitalize the Wellston community.

The primary participants of activities within the MET center are transit dependent and its proximity to the MetroLink station is no coincidence. One goal with the creation of the MET center was to provide members of the Wellston community, plagued with high unemployment rates, with access to activities that will improve their job skills so that they may be competitive for better jobs. 
Neighborhood Intermodal Transfer Facilities

In addition, the St. Louis County Economic Council is coordinating the redevelopment of Cornerstone Industrial Park to encourage new industries to locate in the Wellston area. Infrastructure improvements and financial incentives are some of the tools that the Economic Council has used to encourage companies, such as General Electric and InterGlobal to locate there. Again, transit also played an important role in recruiting these companies as they recognize that the Cornerstone Industrial Park is easily accessible to the area's workforce. In addition, the proposed childcare center, which will be located adjacent to the MetroLink Station, increases the probability that residents of the area can maintain a job.

In order to make transit and employment accessible to Wellston residents, serious rehabilitation and new construction of homes were also required. One of the recommendations of the Urban Land Institute Panel Study was to encourage more home ownership in the Wellston area. Habitat for Humanity precipitated the move for new homes with its "15 Homes in 15 Days" initiative. The impetus for Habitat selecting the Wellston area was its proximity to transit. Habitat for Humanity plans to construct 30-35 new homes in 2002 and 2003. Other private developers have also become involved in increasing the number of new homes for sale in the area. Nearly 110 additional homes will be completed by 2003.

Original funding for the MetroLink stations was secured through the Federal Transit Administration and the local match required to receive federal funds came from the asset value of donated railroad rights-of way, structures, and facilities. The cost of design improvements to the Wellston MetroLink facility in 1996, were approximately one million dollars. FTA paid 75 percent of the MetroLink design improvements, while BSDA and St. Louis County paid the remainder.

Improvements to the MetroLink facility have sparked many other improvements to the area. While Wagner Electric donated several acres of land, including the building that now 
Neighborhood Intermodal Transfer Facilities

houses the MET Center, it was in such poor condition that its renovation costs far exceeded original estimates. However, the most damaging setback to the process was the environmental condition of the donated site. Years of industrial activity left the site contaminated and prospects for selling parts of the land have been hampered by such conditions. The St. Louis Economic Council estimates that it has spent four million dollars on cleaning up the Wagner Electric site and rehabilitating the building which was abandoned in 1980.

Table 7: Advantages and Disadvantages of the Wellston MetroLink Station

\begin{tabular}{|l|l|}
\hline \multicolumn{1}{|c|}{ Advantages } & \multicolumn{1}{c|}{ Disadvantages } \\
\hline encourages private partnership & $\begin{array}{l}\text { high capital costs for original MetroLink } \\
\text { facility }\end{array}$ \\
\hline near community activities & \\
\hline no fare-type barriers & \\
\hline facility is identifiable & \\
\hline supportive level of pedestrian activity & \\
\hline $\begin{array}{l}\text { will be adjacent to various proposed } \\
\text { complementary activities, such as park and } \\
\text { day care }\end{array}$ & \\
\hline
\end{tabular}

One of the main reasons that the Wellston MetroLink Station was selected as a case example for this study was to demonstrate the ability of transit facilities to serve the community beyond its shelters or platforms. Residents of the Wellston area, as well as those from neighboring inner-city communities, welcome this transit facility. They are capitalizing on the opportunities that the increase in mobility has afforded them. 


\section{Section II}

\section{Common Findings}

While the facility types varied, the ultimate mission of each of the presented facilities is the same - providing mobility options. The featured transfer facilities have demonstrated, at various levels, success at providing transportation alternatives and connecting modes. Each made their accomplishments in communities with varied socio-economic backgrounds and under different political atmospheres and funding resources. Two of the facilities were in automobile-dominated areas where most of the commuters chose transit to rid themselves of rush hour traffic or high parking costs. Another two of the facilities were located in communities with low household incomes and greater transit dependency. In addition, each facility was planned and designed using diverse processes, proving that success can be reached by different means. Yet, many of the characteristics of these facilities are similar. In this section, common characteristics of the featured facilities are discussed, identifying the strengths of each facility and creating criteria for future development of neighborhood intermodal facilities. Table 8 identifies the strengths of each featured facility. The common characteristics related to these strengths are then used to provide examples when developing neighborhood intermodal facilities. 
Neighborhood Intermodal Transfer Facilities

Table 8

Criterion One: Intermodal Interaction is Supported and Safe

\begin{tabular}{|c|c|c|c|c|c|c|}
\hline \multirow[b]{2}{*}{ Intermodal Facility } & \multirow{2}{*}{$\begin{array}{c}\text { \# of } \\
\text { Modes } \\
\text { Served }\end{array}$} & \multirow{2}{*}{$\begin{array}{c}\text { \# of } \\
\text { Routes } \\
\text { Served }\end{array}$} & \multicolumn{3}{|c|}{ Measure of Effectiveness } & \multirow{2}{*}{$\begin{array}{l}\text { Could Be } \\
\text { Replicated } \\
\text { on Small } \\
\text { Scale }\end{array}$} \\
\hline & & & $\begin{array}{c}\text { Very } \\
\text { Effective }\end{array}$ & Effective & Ineffective & \\
\hline Margate Terminal & 3 & 7 & $P$ & & & $P$ \\
\hline Washington Shores Superstop & 3 & 6 & & $P$ & & $P$ \\
\hline G.I. Joe Park and Ride Lot & 3 & 2 & & $P$ & & $P$ \\
\hline Fisher's Landing Transit Center & 4 & 7 & $P$ & & & \\
\hline Columbia Intermodal Station & 8 & 10 & $P$ & & & \\
\hline Wellston MetroLink Station & 5 & 6 & $P$ & & & $P$ \\
\hline
\end{tabular}

All of the facilities featured have some form of intermodal interaction. Besides transit service, each facility demonstrated support for various levels of pedestrian activity. As expected, the larger facilities (Fisher's Landing and Columbia Intermodal Station) provide their patrons with several transportation alternatives. The Wellston MetroLink Station is a compact facility; however, it provides effective intermodal service through four modes (rail, bus, pedestrian, and bicycle). The Margate Terminal is an even more compact facility, consisting of a bus shelter on each side of a two-lane road; it also supports four modes (bus-two systems, pedestrian, and bicycle).

It is impressive that the Columbia Intermodal Station supports every mode of transportation available in Wenatchee, including taxi, Amtrak, and Trailways. However, on a neighborhood scale, such variety is not necessary nor usually preferred. In the case of developing a small scale facility, presenting opportunity through modes more commonly found in neighborhoods is key. Those modes usually represent pedestrian, bicycle, transit, and park and ride. This suggests that the Margate Terminal and the Washington Shores Superstop, present the greatest opportunities for transferability on the neighborhood scale. A facility similar to the G.I. Joe Park and Ride could also be a desirable neighborhood 
intermodal facility, especially in outlying, automobile-dominant communities with increased demand for express service into the urban area. The Wellston MetroLink Station, while it supports a mode that is not found in most neighborhoods, is a fine example of intermodal interaction through a rail facility. Wellston's Park and Ride Lot, MetroBus shelters, and pedestrian enhancements could easily stand alone as an effective intermodal facility.

Incident-free interaction between modes addresses how well the facility is designed to minimize accidents and injuries as a result of poor interfacing between modes. The strongest concern for safety deals with pedestrian interaction with transit vehicles and automobiles. Creating a safe environment for pedestrian activity is always a primary concern, particularly in areas which have high captive-rider populations or high levels of pedestrian traffic encouraged by transit-oriented development.

Even for those facilities in areas where pedestrian traffic was low to moderate, steps were taken to address safe pedestrian movement, since walking takes place at some point in every trip - whether transferring between buses or modes. Fisher's Landing's 560-space park and ride lot is divided by strategically placed sidewalks. When vehicle occupants leave their cars, most are within a couple hundred feet of the sidewalk. In turn, the sidewalks guide them to a crosswalk which leads to the bus staging area. The roadway that must be crossed to reach the bus staging area is not open to automobiles, further reducing the opportunity for pedestrian-automobile conflict.

The attention to crosswalks, narrow roadways, and delineated sidewalks is not surprising since most transit organizations recognize that "transit is not effective unless people can get to it, easily and safely." ${ }^{8}$ Safe street crossings were given significant consideration in each of the facilities. Washington Shores, Columbia Station, Fisher's Landing, and Wellston Station each had identifiable crosswalks on streets that were wide enough for

\footnotetext{
${ }^{8}$ WalkBoston. 1998. Improving Pedestrian Access To Transit: An Advocacy Handbook. Washington, DC: Federal Transit Administration, FTA-MA-80-X008.
} 
buses to maneuver through, but narrow enough for pedestrians to feel safe. The flashing warning light above the pedestrian walkway provides additional assurance for pedestrians at the Washington Shores Superstop. Designers of the Wellston MetroLink facility had to take additional precautions since the light rail cars have street-level crossings. The railroad crossing arms and audible signals are deployed when the MetroLink is approaching. This alerts pedestrians, as well as buses and automobiles.

Most of the agencies involved in the development of the facilities believed that it was never too early to begin consideration for pedestrian movement. Most of the facilities examined in the case studies focused on the interaction of two or three modes, one of which was always pedestrian traffic. When selecting a site for the intermodal center, the transit agency in Wenatchee acknowledged in their proposal stage of development that a goal would be for the facility to provide connections to the county's extensive bicycle /pedestrian network.

The neighborhood-scale intermodal facility, regardless of size or type should address pedestrian convenience and safety. Similar to most of the facilities featured, any facility at which walking is integral should have, at a minimum, crosswalks that are clear to both the user and the traffic on the roadway. This is the least expensive method that can be used in creating a safer pedestrian environment. The use of landscaping and decorative walkways to encourage pedestrians to travel the safest paths can also be effective tools for improving pedestrian safety. 
Neighborhood Intermodal Transfer Facilities

Table 9

Criterion Two: Facility Type and Size Reflect Community Needs

\begin{tabular}{|l|c|c|c|c|l|}
\hline \multirow{2}{*}{\multicolumn{1}{c|}{ Intermodal Facility }} & \multirow{2}{*}{$\begin{array}{c}\text { Facility } \\
\text { Type }\end{array}$} & $\begin{array}{c}\text { Facility } \\
\text { Size }\end{array}$ & $\begin{array}{c}\text { Very } \\
\text { Appropriate }\end{array}$ & Appropriate & Inappropriate \\
\hline Margate Terminal & local stop & $<1$ acre & $\mathrm{P}$ & & \\
\hline Washington Shores & local stop & $<1$ acre & $\mathrm{P}$ & & \\
\hline G.I. Joe Park and Ride Lot & park and ride & $<1$ acre & & $\mathrm{P}$ & \\
\hline Fisher's Landing & transit center & $\begin{array}{c}\text { over } 5 \\
\text { acres }\end{array}$ & $\mathrm{P}$ & & \\
\hline Transit Center & transit center & $\begin{array}{c}\text { over } 5 \\
\text { acres }\end{array}$ & $\mathrm{P}$ & & \\
\hline Columbia Intermodal Station & rail facility & $\begin{array}{c}1-5 \\
\text { acres }\end{array}$ & $\mathrm{P}$ & & \\
\hline Wellston MetroLink Station & & & & & \\
\hline
\end{tabular}

Each of the facilities seemed to be the appropriate type of facility as determined by the needs of their respective communities. For instance, the decision to make Washington Shores Superstop an off-street local stop was a reflection of both the number of boardings in the area and the number of routes serving the facility. An on-street facility would have created undue congestion in a community with high levels of pedestrian activity. On the other hand, the on-street facility in Margate is the appropriate size for a facility that has four bus routes and averages less than 100 boardings per day. In addition, neither of the communities surrounding the Margate Terminal nor Washington Shores Superstop is in demand for park and ride services or other modes that have significantly more land requirements. This implies that a smaller facility could be effective. The communities surrounding the G.I. Joe and Fisher's Landing facilities have different needs. Those neighborhoods have a high demand for park and ride services complemented by express bus service. Although Fisher's Landing is definitely a neighborhood facility, the needs of that neighborhood dictate a much larger facility than the Margate Terminal or the Washington Shores Superstop. 
Neighborhood Intermodal Transfer Facilities

Table 10

Criterion Three: Amenities Enhance the User's Experience

\begin{tabular}{|l|c|l|c|c|c|c|}
\hline Amenities & $\begin{array}{l}\text { Margate } \\
\text { Terminal }\end{array}$ & $\begin{array}{l}\text { Washing. } \\
\text { Shores }\end{array}$ & $\begin{array}{l}\text { G.I. Joe } \\
\text { PNR }\end{array}$ & $\begin{array}{l}\text { Fisher's } \\
\text { Landing }\end{array}$ & $\begin{array}{l}\text { Columbia } \\
\text { Station }\end{array}$ & $\begin{array}{l}\text { Wellston } \\
\text { Station }\end{array}$ \\
\hline facility/route sign & $\mathrm{P}$ & $\mathrm{P}$ & $\mathrm{P}$ & $\mathrm{P}$ & $\mathrm{P}$ & $\mathrm{P}$ \\
\hline route/system info & $\mathrm{P}$ & $\mathrm{P}$ & $\mathrm{P}$ & $\mathrm{P}$ & $\mathrm{P}$ & $\mathrm{P}$ \\
\hline specialty paving & & $\mathrm{P}$ & & $\mathrm{P}$ & $\mathrm{P}$ & $\mathrm{P}$ \\
\hline passenger shelter & $\mathrm{P}$ & $\mathrm{P}$ & $\mathrm{P}$ & $\mathrm{P}$ & $\mathrm{P}$ & $\mathrm{P}$ \\
\hline seating & $\mathrm{P}$ & $\mathrm{P}$ & $\mathrm{P}$ & $\mathrm{P}$ & $\mathrm{P}$ & $\mathrm{P}$ \\
\hline trash receptacles & $\mathrm{P}$ & $\mathrm{P}$ & $\mathrm{P}$ & $\mathrm{P}$ & $\mathrm{P}$ & $\mathrm{P}$ \\
\hline newspaper stand & $\mathrm{P}$ & $\mathrm{P}$ & & $\mathrm{P}$ & $\mathrm{P}$ & $\mathrm{P}$ \\
\hline landscaping & $\mathrm{P}$ & $\mathrm{P}$ & & $\mathrm{P}$ & $\mathrm{P}$ & $\mathrm{P}$ \\
\hline lighting & $\mathrm{P}$ & $\mathrm{P}$ & $\mathrm{P}$ & $\mathrm{P}$ & $\mathrm{P}$ & $\mathrm{P}$ \\
\hline bicycle storage & $\mathrm{P}$ & $\mathrm{P}$ & & $\mathrm{P}$ & $\mathrm{P}$ & $\mathrm{P}$ \\
\hline drinking fountain & & & & $\mathrm{P}$ & $\mathrm{P}$ & $\mathrm{P}$ \\
\hline fare/change machine & & & & $\mathrm{P}$ & $\mathrm{P}$ & $\mathrm{P}$ \\
\hline retail kiosks & & & & $\mathrm{P}$ & $\mathrm{P}$ & \\
\hline crosswalks & $\mathrm{P}$ & $\mathrm{P}$ & $\mathrm{P}$ & $\mathrm{P}$ & $\mathrm{P}$ & $\mathrm{P}$ \\
\hline public telephone & & & & $\mathrm{P}$ & $\mathrm{P}$ & $\mathrm{P}$ \\
\hline advertising & $\mathrm{P}$ & $\mathrm{P}$ & & $\mathrm{P}$ & $\mathrm{P}$ & $\mathrm{P}$ \\
\hline restrooms & & & & $\mathrm{P}$ & $\mathrm{P}$ & $\mathrm{P}$ \\
\hline
\end{tabular}

Table 10 shows which amenities were common among the example sites. Some of the amenities that were consistently present at all of the sites are discussed below.

Each facility, regardless of scale or modes served, had shelters to protect patrons from the sun and inclement weather. Margate, the G.I. Joe Park and Ride, and Wellston MetroBus station had typical bus shelters that are enclosed on three sides. They provide an unobstructed view into and out of the shelter, but have slots at the bottom to facilitate air 
movement. Washington Shores and the Wellston MetroLink Station have canopy-type shelters which also allow for air movement. These types of shelters allow coverage for a greater number of people, consistent with the number of daily boardings at those facilities. The transfer centers also exhibited similar seating features.

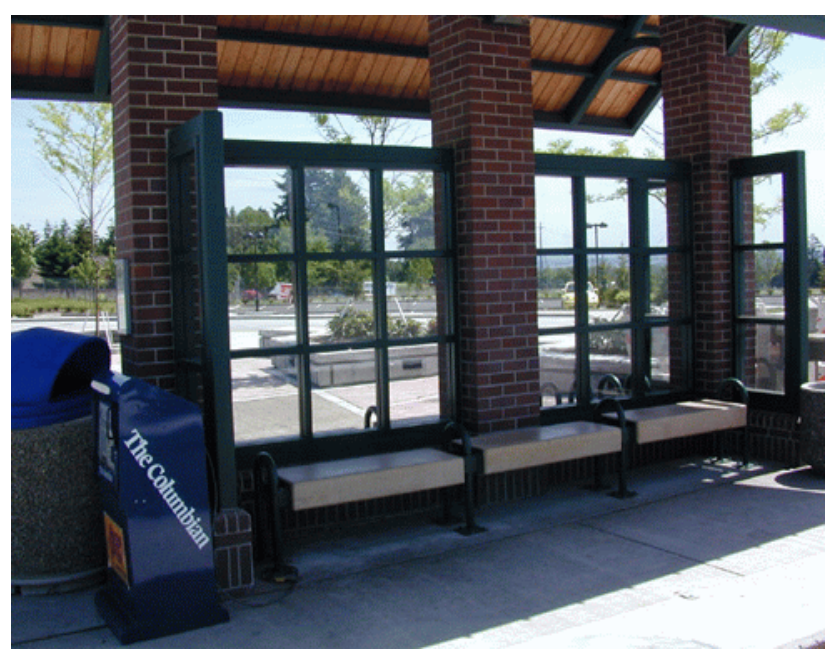

Fisher's Landing has abundant seating for its waiting passengers.

Most of the transit agencies were concerned with providing seating for the comfort of their patrons, but not providing an area that was inviting to loiterers. In response, several agencies installed seating that is not conducive to reclining or sitting for long periods of time. Washington Shores, as with all of Lynx's newer transit facilities, has both circularshaped seats made from plastic or perforated metal and wave benches. Lynx has found that the seating is basically vandal-resistant. Leaning rails are also located at Washington Shores allowing riders to relax in a standing position as an alternative to traditional benches. Seating used at other facilities featured in the case studies are concrete or perforated metal benches with rails down the middle, which also prohibit lounging ( Fisher's Landing and G.I. Joe Park and Ride). The Wellston Metrolink Station has semicircle shaped concrete seating and the MetroBus area has typical bench seating both inside and outside of the shelters. In all cases, there was an effort to make seating available and 
convenient, although not necessarily comfortable if used for long periods of time. Consequently, none of the facilities reported loitering problems.

Bicycle storage was available at all of the facilities (except the G.I. Joe Park and Ride lot), but did not seem greatly utilized at most of them. This may be attributed to a couple of factors. First, all of the facilities featured are served by buses with bus racks mounted in front, allowing patrons to mount their bicycles on the bus, rather than leave them at the facility. Also, automobile-dominance of most communities suggests that bicycle use is more for recreation than transportation purposes, as seen at the Margate Terminal. The exception was Fisher's Landing, which is located in a community where travel by automobile prevails. All eight bicycle storage lockers are occupied.

Bicycle storage types range from racks or rails to enclosed lockers. Fisher's Landing

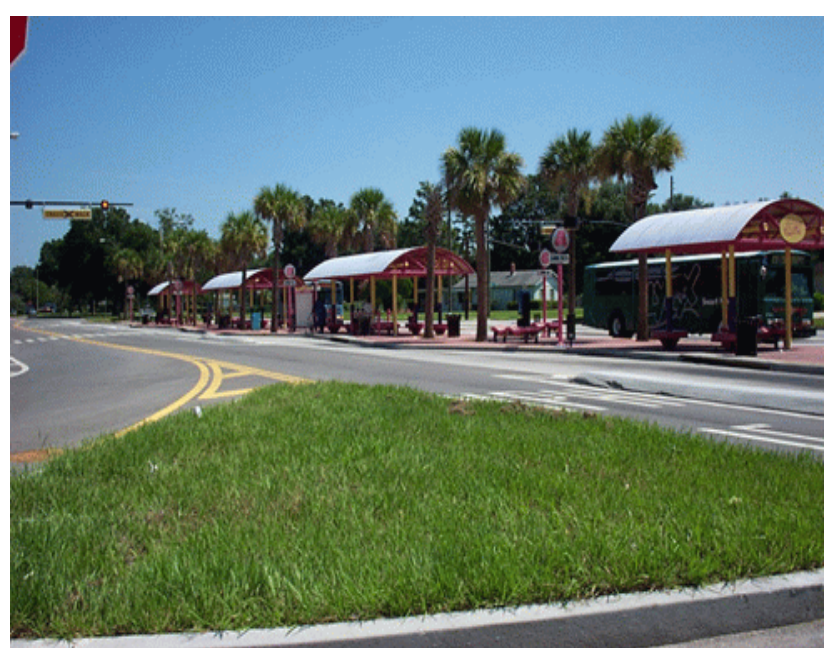

Lynx's Washington Shores Superstop boasts over a dozen palm trees.

installed the enclosed bicycle storage lockers, which were considerably more expensive than the typical bicycle racks or rails. However, they have found that the lockers are occupied 100 percent of the time, or at least they are perceived to be occupied because they are rented on a monthly basis. Typical bicycle racks are capable of storing more 
Neighborhood Intermodal Transfer Facilities

bikes and require less space. While space is not much of a factor at Fisher's Landing, it is usually a major consideration at most small-scale facilities.

Table 10 also suggests that, as expected, larger facilities have the most amenities; while the local stops and park and ride lots are limited to essentials. Noticeably absent from the smaller facilities are drinking fountains, restrooms, public telephones, landscaping, and retail kiosks. Except for landscaping, it can be argued that these amenities have a minimal effect on facility usage levels. However, landscaping can have multiple effects at a transportation facility. The palm trees and decorative sidewalks at Washington Shores Superstop support the festive and bold atmosphere that Lynx desires. Fisher's Landing uses natural vegetation swales as both attractive landscaping and physical barriers to encourage pedestrians to use the sidewalks rather than cut across the parking lot. The landscaping at all of the facilities was carefully selected to have minimal watering requirements.

Table 11

Criterion Four: Facility is Accessible to Everyone (ADA Compliant)

\begin{tabular}{|l|c|c|c|}
\hline \multirow{2}{*}{\multicolumn{1}{|c|}{ Intermodal Facility }} & \multicolumn{3}{c|}{ Measure of Accessibility } \\
\cline { 2 - 4 } & Very Accessible & Accessible & Inaccessible \\
\hline Margate Terminal & & $\mathrm{P}$ & \\
\hline Washington Shores Superstop & & $\mathrm{P}$ & \\
\hline G.I. Joe Park and Ride Lot & & $\mathrm{P}$ & \\
\hline Fisher's Landing Transit Center & & $\mathrm{P}$ & \\
\hline Columbia Intermodal Station & & $\mathrm{P}$ & \\
\hline Wellston MetroLink Station & & $\mathrm{P}$ & \\
\hline
\end{tabular}

It is very important that an intermodal facility be accessible to all, including the disabled and elderly. All of the facilities were designed to minimize physical barriers to the disabled. Exceptions are related to providing audible route information for the hearing-impaired and 
Neighborhood Intermodal Transfer Facilities

information in Braille for the sight-impaired. None of the featured facilities were participating in such practices. However, Fisher's Landing and Columbia Station have personnel on-duty to assist patrons with sight and hearing impairments. In general, facilities in which transit is the primary mode rely on bus operators to assist the sightimpaired when boarding the buses and to call out primary stops (as required by law).

Table 12

Criterion Five: Transferability Between Modes is Feasible and Reliable

\begin{tabular}{|l|c|c|c|}
\hline \multirow{2}{*}{\multicolumn{1}{|c|}{ Intermodal Facility }} & \multicolumn{3}{|c|}{ Measure of Transferability } \\
\cline { 2 - 4 } & $\begin{array}{c}\text { Very Feasible } \\
\text { and Reliable }\end{array}$ & $\begin{array}{c}\text { Feasible and/or } \\
\text { Reliable }\end{array}$ & $\begin{array}{c}\text { Not Feasible nor } \\
\text { Reliable }\end{array}$ \\
\hline Margate Terminal & & $\mathrm{P}$ & \\
\hline Washington Shores Superstop & $\mathrm{P}$ & & \\
\hline G.I. Joe Park and Ride Lot & $\mathrm{P}$ & & \\
\hline Fisher's Landing Transit Center & $\mathrm{P}$ & & \\
\hline Columbia Intermodal Station & $\mathrm{P}$ & & \\
\hline Wellston MetroLink Station & $\mathrm{P}$ & & \\
\hline
\end{tabular}

The facilities presented involved interaction between at least two modes. An indicator of effectiveness when evaluating intermodal transfer facilities is how feasible and reliable it is to transfer between modes and routes. Obviously, the design and operation of any intermodal transfer facility should require that transfers be feasible. However, some of the greatest limitations to transfers are uncoordinated fares and uncoordinated schedules between routes and modes (poor connections). Even when the schedules are coordinated, unreliable service negates that coordination.

Most of the facilities did not appear to have many barriers to transfers. Multiple fares were only an issue at the Margate Terminal and the Columbia Station. There is no ability to transfer to/from a Margate bus onto a Broward County Transit bus without paying an additional fare. Nor does the Columbia Station have the capability to coordinate the fare 
Neighborhood Intermodal Transfer Facilities

of the seven modes served at that facility. Presumably such coordination is difficult since inter-city and inner-city transportation alternatives are offered. Patrons of the MetroLink and MetroBus facilities can transfer between modes at the Wellston Station. This is much easier to accomplish since the local transit agency is responsible for both primary modes at the facility.

An additional barrier to transfers at the Margate Terminal is related to the additional walking distance to connect to BCT buses. As mentioned in the case study description, BCT no longer pulls its buses into the Margate Terminal and, instead, stops a block away to minimize congestion. This could affect a passenger's ability to make a connection.

\section{Table 13}

Criterion Six: Reliable passenger information and service are provided

\begin{tabular}{|l|c|c|}
\hline \multicolumn{1}{|c|}{ Intermodal Facility } & $\begin{array}{c}\text { Mode or Route Identified } \\
\text { by Sign }\end{array}$ & $\begin{array}{c}\text { Current Mode or Route } \\
\text { Information }\end{array}$ \\
\hline Margate Terminal & $\mathrm{P}$ & $\mathrm{P}$ \\
\hline Washington Shores Superstop & $\mathrm{P}$ & $\mathrm{P}$ \\
\hline G.l. Joe Park and Ride Lot & $\mathrm{P}$ & $\mathrm{P}$ \\
\hline Fisher's Landing Transit Center & $\mathrm{P}$ & $\mathrm{P}$ \\
\hline Columbia Intermodal Station & $\mathrm{P}$ & $\mathrm{P}$ \\
\hline Wellston MetroLink Station & $\mathrm{P}$ & \\
\hline
\end{tabular}

The table illustrates that signage is one common feature of all the facilities. The level of detail on the signs varied for each facility - but each, at a minimum, included the route number. Permanently grounded entry signs were installed at Fisher's Landing, Columbia Station, and G.I. Joe Park and Ride lot, while facility identification kiosks or signs were used at Wellston MetroLink Station and Washington Shores Superstop. The Margate Inner-City Transit is identified on the route signs at the Margate Terminal. In all cases, the facilities were identifiable by patrons. This is key when attempting to integrate the facility into a community and create facility recognition. 
Neighborhood Intermodal Transfer Facilities

Available and reliable route or mode information was also an important feature of the facilities explored. All of the facilities featured in this report provide general route information, and all but one of them provide detailed route and mode information to make using the facility more convenient and user-friendly. Free-standing information kiosks are used at the Lynx facility, as well as at Fisher's Landing, Columbia Station and Wellston MetroLink. At Tri-Met's facility in Portland, route and system information is attached to the shelters behind vandal-resistant plastic.

\section{Table 14}

Criterion Seven: Community Involvement is Integrated in the Planning and Design

\begin{tabular}{|l|c|c|c|}
\hline \multirow{2}{*}{\multicolumn{1}{c|}{ Intermodal Facility }} & \multicolumn{2}{c|}{ Measure of Community Involvement } \\
\cline { 2 - 4 } & $\begin{array}{c}\text { Much } \\
\text { Community } \\
\text { Involvement }\end{array}$ & $\begin{array}{c}\text { Some } \\
\text { Community } \\
\text { Involvement }\end{array}$ & $\begin{array}{c}\text { No Community } \\
\text { Involvement }\end{array}$ \\
\hline Margate Terminal & & & $\mathrm{P}$ \\
\hline Washington Shores Superstop & $\mathrm{P}$ & & \\
\hline G.I. Joe Park and Ride Lot & & $\mathrm{P}$ & \\
\hline Fisher's Landing Transit Center & $\mathrm{P}$ & & \\
\hline Columbia Intermodal Station & $\mathrm{P}$ & & \\
\hline Wellston MetroLink Station & $\mathrm{P}$ & & \\
\hline
\end{tabular}

Most of the facilities presented in this report were planned and designed following significant community involvement. For those facilities, the development was community driven so that the community could (1) "buy-in" to the presence of the facility; (2) have a say in the design of the facility; and (3) generate pride or ownership in the facility.

Washington Shores Superstop, Fisher's Landing, Columbia Station, and the Wellston MetroLink Station were each involved in at least two years of public support building and community involvement. For Fisher's Landing, the involvement came early in the process as C-Tran staff attempted to address the already growing opposition to the proposed 
Neighborhood Intermodal Transfer Facilities

facility. The facility proposed was in an auto-dominated community that saw little value in transit service, except for express service which was utilized for daily commutes to either downtown Portland or Vancouver. In efforts to dispel myths about transit facilities and to offer the community the chance to assist in creating a facility that provided value and transportation alternatives, C-Tran involved itself in an extensive public involvement campaign. The result is a facility that serves as both an activity and transportation center and that featured public input at every point in the process.

Table 15

Criterion Eight: Opportunities for Community Partnerships Exist

\begin{tabular}{|c|c|c|c|}
\hline \multirow[b]{2}{*}{ Intermodal Facility } & \multicolumn{2}{|c|}{$\begin{array}{l}\text { Measure of Partnership } \\
\text { Opportunities }\end{array}$} & \multirow[b]{2}{*}{ Partners } \\
\hline & $\begin{array}{c}\text { Some } \\
\text { Partnership } \\
\text { Opportunity }\end{array}$ & $\begin{array}{c}\text { No } \\
\text { Partnership } \\
\text { Opportunity }\end{array}$ & \\
\hline Margate Terminal & $P$ & & $\begin{array}{c}\text { Broward County Transit; City o } \\
\text { Coconut Creek }\end{array}$ \\
\hline Washington Shores Superstop & $\mathrm{P}$ & & Walt Disney World \\
\hline G.I. Joe Park and Ride Lot & $\mathrm{P}$ & & G.I. Joe Sports and Auto Store \\
\hline Fisher's Landing Transit Center & $P$ & & local schools, local police \\
\hline Columbia Intermodal Station & $P$ & & $\begin{array}{l}\text { Amtrak, Trailways, taxi } \\
\text { companies, many more }\end{array}$ \\
\hline Wellston MetroLink Station & $P$ & & $\begin{array}{l}\text { St. Louis Economic Council } \\
\text { and many more }\end{array}$ \\
\hline
\end{tabular}

Partnership was integral in each of the case studies. For Margate, the partnership is actually related to the service; however, its "system within a system" through Broward County Transit's Community Bus Service is a fine example of working together for the benefit of the community. While BCT's initial goals may have been to create feeder service for their trunk line service, it participated in efforts that created a community system that generated 179,000 passenger trips in 2000 . 
Neighborhood Intermodal Transfer Facilities

The success that Tri-Met has had with the owners of its shared park and ride lots are evident in numbers. Tri-Met has 21 shared park and ride lots that account for over 20 percent of their park and ride parking space allocation. In anticipation of losing park and ride spaces, Tri-Met successfully made arrangements with the G.I. Joe Auto and Sports Store. By offering a win-win relationship, several of the Milwaukie community commuters are able to use the park and ride to access express service into the Portland CBD. The shared lot presents expenses that are far less than independent park and ride facilities owned by the transit agency. In exchange, the shopping center receives assistance with parking lot maintenance.

There is also a partnership between Lynx and Walt Disney World to enhance opportunities for Disney workers to reach the theme parks via transit.

Finally, the partnership exhibited in Wellston between the Bi-State Development Agency and several other public and private entities has caught the attention of transit agencies around the country. Some believe that the simple siting of the MetroLink station in Wellston has sparked proposals (and much action) to ignite renewal in a community that some had written off. Few would deny that Wellston community improvements would have been much slower to occur (if they would have occurred at all) had the MetroLink facility not located there. On the other hand, the Wellston MetroLink Station may have never experienced the ridership success that it has without the supporting activities that have developed and continue to develop as a result of the many partnerships established in efforts to improve job, education, and housing opportunities in the Wellston community. 
Neighborhood Intermodal Transfer Facilities

Section III

\section{Implications for Neighborhood Intermodal Facilities in Florida}

Sections I and II identified the common characteristics designed to enhance intermodal opportunities through a variety of facility types. These characteristics may be used in the development of an intermodal facility that balances the needs of the community with spatial and funding limitations.

The guidelines presented in this section are based on the design and planning experiences of facilities featured in the case studies. They are examples that may be used in potential or existing development in communities throughout Florida. The guidelines can be used to provide transit agencies, private developers, or others participating in the development of neighborhood intermodal facilities with some of the techniques and attributes that have contributed to functional and attractive facilities elsewhere.

Generally, the requirements of a neighborhood intermodal facility in Florida may not differ greatly from one which is located elsewhere. However, weather conditions and demographic profiles are factors which might impact the elements of a transfer facility in Florida. Specifically, an intermodal transportation facility, which will presumably involve transfers and require passengers to wait between those transfers, should include adequate shelter from sun and rain. The 2000 Census data reveal that Florida has the greatest percentage of population over the age of 65 , accounting for nearly 18 percent, compared to 12 percent for the United States. This presents another reason why shelters and adequate seating should be considered for intermodal facilities in Florida. These and other considerations are made in this section, as minimum requirements for the development of an intermodal transfer facility in Florida neighborhoods are established. While most of the following recommendations may be applied to any of the featured facility types, when one refers to a particular type, it is noted. 


\section{Minimum Elements and Amenities}

Below is a list of design elements and amenities that, at a minimum, should be integrated into a neighborhood intermodal facility in order to be accessible, functional, comfortable, and attractive. More detailed explanations follow below.

- $\quad$ Create a pedestrian-friendly environment by designing connections that stand out and signify priority over automobiles.

- Install functional bicycle racks in visible locations to alert the neighborhood that bicycling is welcome at the facility and that users' bicycles will be safe.

- Ensure the facility is a recognizable feature of the neighborhood through informative and ornate signage.

- Display current route and mode information using a method that allows easy modification in case of schedule or route changes.

- Install shelters and seating for passengers who are transferring between routes or modes.

- Ensure adequate lighting is placed throughout the facility for the safety and convenience of users.

- Include public art and landscaping to enhance the attractiveness of the neighborhood facility.

- Coordinate fares and schedules of multiple operators.

- Involve the community in the planning, design, and operation of the facility.

- Encourage community partnerships to instill a team approach for the facility's success. 
Neighborhood Intermodal Transfer Facilities

\section{Create A Pedestrian-Friendly Environment by Designing Connections That Stand Out and Signify Priority Over Automobiles}

Since walking is the essential mode in any transfer facility, making it safe and convenient is critical. When developing an intermodal transfer facility, goals related to pedestrian mobility are to (1) provide safe and convenient access from the facility to the street and nearby destinations; (2) demarcate the crosswalks to alert drivers of pedestrians; and (3) install curb cuts to ensure accessibility to all persons. In achieving these goals it is important that a sense of priority for pedestrians is established which will be reflected by slower traffic and a more cautious environment.

One of the first tasks involved in providing safe and convenient access from the facility is to create wide, inviting walkways with a sufficient buffer from vehicles. These walkways should offer connection between the facility and likely destinations, including subdivisions. This creates an environment for the pedestrian that is safe and provides them the opportunity to travel direct routes with minimal opportunities for automobile-pedestrian conflict. Measures should also be taken to make the walkways appear inviting or festive. This may include using decorative or textured walkways, ornamental light fixtures that complement the area, or banners that reflect a neighborhood or facility theme. These features also serve as a buffer between passing vehicles on the street and the pedestrians, further creating a sense of security. Such attention to walkways should also be applied to those internal to a park and ride facility, as seen in the Fisher's Landing Transit Center.

Although such attempts are often rebuffed by developers and occupants of residential subdivisions, pedestrian linkages between subdivisions and transportation facilities create a more walkable community and often reduce the distance between the facility and the homes.

Intersections nearest to an intermodal facility should also have delineated crosswalks to alert drivers of possible pedestrian crossings. The most functional crosswalks are elevated 
or consist of pavement texturing rather than paint. Paint, as in the case of the Margate Terminal, tends to fade and requires more frequent maintenance. On the other hand, elevated crosswalks or those designed with varied paving textures are durable techniques which also distinguish the pedestrian infrastructure from that designed for a car or bus. This is very important when attempting to create an intermodal environment.

In conjunction with varying the presentation of the crosswalk, the use of curb extensions can also create a safer pedestrian environment by reducing the street crossing distances for pedestrians and the speed of vehicular traffic. Curb cuts allow pedestrians who are waiting to cross the street a better view of vehicular traffic and are, conversely, also more visible to drivers.

Finally, intersections nearest to an intermodal facility should have appropriate curb cut ramps. Such ramps allow elderly and disabled pedestrians safe access between the street and the facility. Design standards should meet or exceed specifications in accordance with the Americans with Disabilities Act of 1990 (49 CFR Part 37).

\section{Install Functional Bicycle Racks in Visible Locations to Alert the Neighborhood That Bicycling is Welcome at the Facility and That Users' Bicycles Will Be Safe}

Bicycle accommodation at intermodal transfer facilities is more commonly occurring as communities begin to explore innovative techniques of integrating bicycle use with other modes, particularly mass transit. Being able to carry bicycles on transit has been one of the greatest contributors to increased transit usage over the past five years. Those who choose to park their bicycles at the bus stop rather than use bike racks on buses have found that intermodal transfer facilities lack secure places to park their equipment. ${ }^{9}$ In

\footnotetext{
${ }^{9}$ Implementing Bicycle Improvements at the Local Level: Bike Guide On-Line. 1998. Prepared for the Federal Highway Administration. Accessed at http://www.bikewalk.org/bike guide online.html (August 2001).
} 


\section{Neighborhood Intermodal Transfer Facilities}

addition to inadequate access to intermodal facilities, this has been the greatest deterrent to intermodal transportation.

Before selecting a site for an intermodal transfer facility, the developer should determine if the surrounding area is accessible by bicycle and what infrastructure modifications would be required to make it more accessible. When designing the facility, the provision of adequate and secure bicycle parking is equally important. Racks or enclosed lockers are the most popular methods of securing bicycles at transit facilities.

Enclosed lockers, such as the ones used at the Fisher's Landing Transit Center, are more

Interesting Fact:

BIKESTATIONS are attended bike-transit centers that offer secure, valet bicycle parking and other amenities to encourage the use of bicycles as a transportation mode. Currently three facilities are in operation in California: Long Beach, Palo Alto, and Berkeley; and several communities across the country are in various stages of planning and implementation. More information may be obtained from www.bikestation.org.

expensive than traditional bike racks. Traditional bicycle securement racks range between $\$ 75$ and $\$ 300$, while enclosed lockers range between $\$ 1,600$ and $\$ 3,300$. Traditional racks may vary greatly in capacity, but generally accommodate between two and eight bicycles. Enclosed lockers typically accommodate one or two bicycles, require greater space, and may pose problems related to misuse. However, they also provide an environment more secure from theft and the weather - which is particularly important to ardent bicyclists. BikeLids allow cyclists to roll their bicycles into a shell and secure them with their own locks. BikeLids are made of polyethylene over a steel shell, are designed to protect bicycles from theft and weather. BikeLids run approximately $\$ 1,000$ each and one lid accommodates one bicycle. BikeLids also have advertisement capabilities. 
Bicycle storage should be located so that they are visible but do not obstruct pedestrian walkways. They should also reflect the style, color, or theme of the transit facility.

\section{Ensure the Facility is a Recognizable Feature of the Neighborhood Through Informative and Ornate Signage}

If a neighborhood facility is to be integrated into the everyday activities of a community, it should be identified as a part of that community. The community's name should be reflected in the name of the facility giving it "ownership." Signage should also include the name of the transportation agencies representing the modes at the facility to illustrate their commitment to intermodalism.

Facility signage should mirror the scale of the facility. For instance, an intermodal local transit stop that consists of a shelter and bench is probably adequately identifiable by a posted sign or shelter emblem. However, a transit center may be best served by anchored or more permanent signage near the entrance of the facility. In either case, the signage should be consistent with similar facilities, as was seen in the G.I. Joe Park and Ride lot.

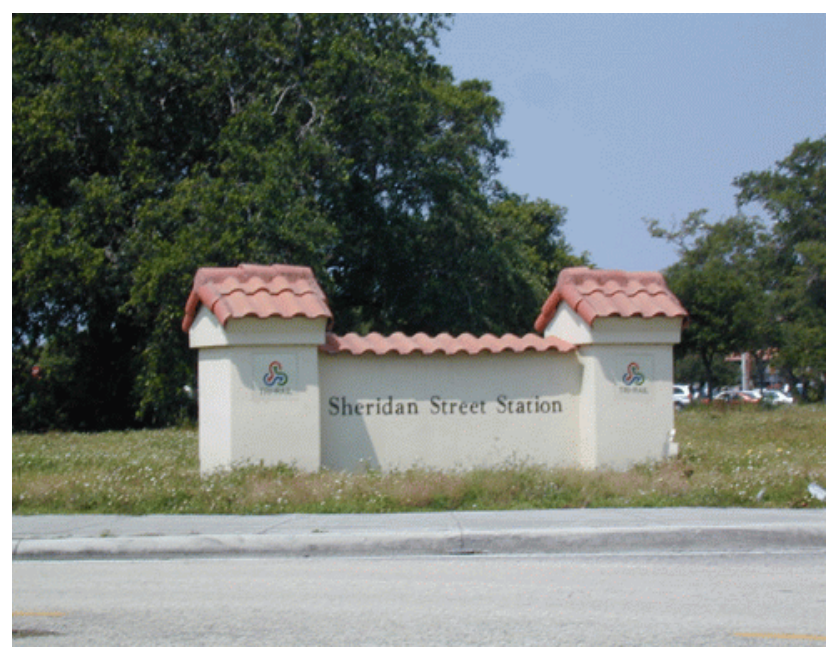

This permanent sign serves as an identifier to a TriRail facility in Broward County and uses a style that is consistent with those used at other Tri-Rail facilities.

This creates a familiarity not only with people who live and work in the area, but also with those who use other transportation facilities in the area. 


\section{Neighborhood Intermodal Transfer Facilities}

Ornate or decorative signage, while not a necessary feature, creates a festive entry point into the facility. Often ornate signage is consistent throughout the transit system or it may represent historic aspect of a neighborhood or architectural design of the facility. In either case, signage indicates an investment to facility patrons.

\section{Display Current Route and Mode Information Using a Method That is Easily Modified in Case of Schedule or Route Changes}

While facility signage is important for identification purposes, route and mode information signs are important to the successful interaction between modes. Information signs which identify points of access for transit routes, as well as route numbers, are critical to the ability of users to transfer between routes and modes efficiently. The types may range from bus stop pole signage to elaborate route system information displays. ${ }^{10}$ Pole signs

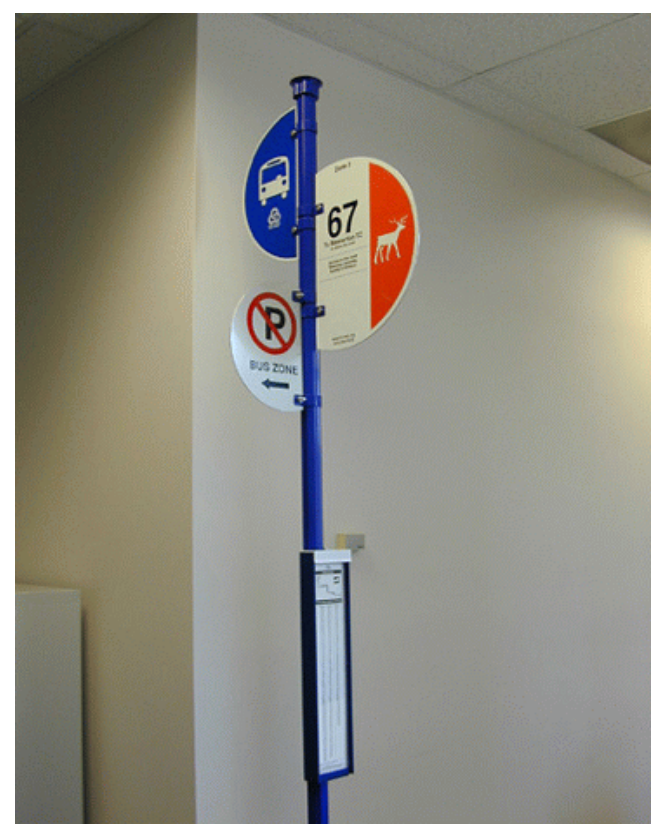

This is an example of the new multidimensional signage that Tri-Met is preparing to introduce in its system.

\footnotetext{
${ }^{10}$ Design Guidelines for Bus and Light Rail Facilities, Sacramento Regional Transit District, April 1991.
} 


\section{Neighborhood Intermodal Transfer Facilities}

are the simplest, and are generally the least expensive. Most transit systems use pole signs, but the information is often inadequate, lacking route numbers and destinations. Instead, pole signs should include system identification, route numbers, and destinations. Modifying such signs when route information changes, however, can become very expensive if frequent system changes occur. Pole signs are also limited (due to size and cost of replacement) by the amount of useful information that can be illustrated. More detailed information, such as schedules and route maps are generally not displayed on pole signs.

Information displays are generally free-standing or posted inside of shelters and usually involve more expensive hardware, consisting of a frame and vandal-resistant plastic covering. As is the case with Lynx and Tri-Met information displays, modifications to system routes require changing the presentation inside of the display, rather than the display itself. It is, therefore, easier and cheaper to modify information display boards rather than pole signs.

The presentation inside the display may include route maps and schedule information. Other useful tools presented in the display are fare information, system map and schedules, and transit customer service contact information. The information displays present the greatest opportunity to facilitate intermodal interaction. However, if funding limitations prevent the acquiring of such signs, at a minimum, pole signage should be installed. In some areas, both are used.

Although none of the facilities featured in this report use real-time route information, estimated time of arrival (ETA) kiosks are an effective way of ensuring the availability of current route information at intermodal transfer facilities.

Install Shelters and Seating for Passengers Who Are Transferring Between Routes or Modes 


\section{Neighborhood Intermodal Transfer Facilities}

Besides reliability of service, presentation of the passenger waiting area could be the most important factor in attracting and keeping riders. As mentioned earlier in this section, in Florida adequate shelters and benches are critical at transfer facilities. While funding limitation may not allow them to exist at every bus stop, they should be considered essential furnishings at intermodal transfer facilities where multiple routes and modes converge.

Shelter types range from aluminum frame three-sided coverings with transparent panels to open-air canopies. A case can be made for both types considering Florida's wet and sunny weather conditions. The enclosed shelters provide better protection from the rain and windy weather, but can be incredibly uncomfortable in the smoldering heat. On the other hand, the open-air canopy, as the name would suggest, allows a breeze to move through the shelter, and it is not as effective against wind and rain. In either case, shelters should be durable and vandal-resistant. Shelters should also be consistent with architecture of the facility and neighborhood. Shelter advertising is an effective mechanism used by many transportation agencies are using to generate revenue to support the maintenance costs.

In the Planning and Design for Transit Handbook, Tri-Met establishes that shelters should be located downstream from the bus stop landing pads and between 6-20 feet from the front door of the transit vehicle (p. 3-26). Placing the facility "downstream" from the landing pad allows the driver an unobstructed view of the bus stop area and keeps waiting passengers away from the approaching bus. A placement of 6-20 feet from the bus stop landing area also allows sufficient circulation space for patrons in mobility devices, yet facilitates timely passenger loading.

Benches are generally installed within shelters, but they can also be installed independently. The number of passengers accommodated and the style of seating may 


\section{Neighborhood Intermodal Transfer Facilities}

depend on facility type. Seating at a facility designed to promote interaction between modes should be abundant, since transfers generally require waiting.

As with the shelters, seating should be durable and reflect the architecture of the facility or neighborhood. Most transit agencies are selecting seating without backs to allow seating from either direction. A common style of seating being used allows flexible sitting patterns and number of participants, and discourages sleeping or reclining (Lynx, p. 5.5) through the use of bars or handles and curved benches. Perforated plastic or metal seating is an optimal selection in the Florida climate and also tends to be more vandalresistant.

\section{Ensure Adequate Lighting is Placed Throughout the Facility for the Safety and Convenience of Users}

Good lighting creates a safer environment for patrons of a facility, while also allowing them visual access to schedule information and advertisements. In the case of local transit stops and shared use park and ride lots, existing street lighting may be sufficient; however, when establishing transit centers and independent park and ride lots, facility-specific lighting must be installed.

Lighting should be vandal-resistant and should require little maintenance. Some transit agencies are exploring the use of solar lighting. However, as stated in Lynx's Customer Amenities Manual, solar lighting requires the establishment of back-up lighting alternatives (p. 5.15). ${ }^{11}$ An outdoor solar lighting company in Florida is marketing a solar-powered light that can be activated by waiting transit patrons. In addition to providing security for the waiting passenger, the light signifies to the bus operator that someone is waiting at the stop.

\footnotetext{
${ }^{11}$ Herbert-Halback and Associates Inc. 1994 (Revised in 2000 by Lynx). Customer Amenities Manual. Prepared for Central Florida Regional Transportation Authority (Lynx).
} 


\section{Neighborhood Intermodal Transfer Facilities}

Lighting, like other facility furnishings should compliment the neighborhood or the theme of the facility. In residential areas, it is also important for the lighting to shine down at the surface or concentrate on the shelter, so that it does not offend nearby residents.

\section{Include Public Art and Landscaping to Enhance the Attractiveness of the Neighborhood Facility}

While public art and landscaping are generally considered aesthetic features, they also contribute to the functionality of the facility. Art in public places has become a trend used all over the country in an effort to accentuate the relationship between the community and the transit facility. Public art can be integrated into the design of a neighborhood intermodal transfer facility or a temporary display of public art can be used to highlight the talent of local artists. In either case, art is instrumental in creating a customer-friendly, neighborhood-oriented environment.

When public art takes the form of sculptures or intricate pieces, it can be an expensive venture. As a result, many communities are relying on neighborhood designs and local talent, specifically area students, to liven up their transit facilities. Such display may be more valuable in a neighborhood setting as it best represents the expressions of those that live near and use the facility.

Visual enhancement can also be achieved through landscaping. Landscaping can provide shade on sunny days, encourage pedestrian activity, and break up the monotony of concrete or paving in the facility. When cared for properly, landscaping can help the facility retain its attractiveness. While landscaping can be elaborate, simple displays can be just as effective. As was the case in Fisher's Landing, wetland mitigation plants were used to create a native environment and temper traffic in the park and ride lot so that it could safely serve pedestrians.

\section{Coordinate Fares and Schedules of Multiple Operators}




\section{Neighborhood Intermodal Transfer Facilities}

Most of the recommendations presented thus far are design-related; however, service- or policy-related guidelines are also critical to the success of intermodal integration at a neighborhood facility. Unfortunately, many transfer facilities become intermodal haphazardly or are not planned as such. As a result, connectivity between modes or routes is inconsistent and unreliable, both of which can doom the facility. To avoid this potential source of failure, it is important that all modes served are represented in the planning and design of the facility. This will facilitate coordination between public transportation agencies and bicycle and pedestrian activists.

Coordination should address having similar fare instruments and coordinating routes and schedules so that connections are reasonable and coverage is maximized. While it is not always financially feasible to allow free transfers between routes or modes, discussion between representatives should address how it and other techniques can be used to encourage more interaction between modes and more reliance upon transportation modes other than the single-occupant vehicle. 
Involve the Community in the Planning, Design, and Operation of the Facility

Community participation efforts should be integrated early into the development of a neighborhood intermodal facility to create a sense of trust and usefulness in the process. The community, who is expected to use the facility, must feel as if it represents their needs. Instead of creating a process through which residents may indicate their approval or disapproval, a true participation effort will give them a fundamental role in integrating transportation options into their communities.

Opportunities for community participation will involve each segment of the population, including the youth, elderly, and disabled. Examples of participation strategies are:

- $\quad$ transportation presentations at neighborhood meetings

- $\quad$ neighborhood focus groups

- community surveys

- design charettes

- $\quad$ tree planting by residents

- community gardens

- local artist displays

- rotation of community organizations to perform modest maintenance duties (similar to adopt-a-highway)

Activities like these can be instrumental in generating pride in the facility and demonstrating that the transit facility has a mission beyond providing transportation alternatives.

Encourage Community Partnerships to Instill a Team Approach to the Facility's Success 
Neighborhood Intermodal Transfer Facilities

The Role of Transit in Creating Livable Metropolitan Communities explores, in part, how transit is enhancing communities through public and private partnerships. ${ }^{12}$ The effects of partnerships can improve the quality of service and the experience of the patrons at intermodal facilities, as seen in the relationship between multiple transit operators at the Margate Terminal. Development around the Wellston MetroLink Station illustrates how partnerships can extend beyond the walls of a facility. In both cases, the community received the greatest benefits. Examples of partnerships described in the abovereferenced report are presented below. Participating partners follow the project title in parentheses.

- $\quad$ The Portland Saturday Market (Tri-Met and Saturday Market Organizers)

- Health Station at Roxbury Crossing T-Station (Massachusetts Bay Transportation Authority [MBTA] and Whittier Street Neighborhood Health Center)

- Downtown Saturday Night (Sun Tran and Tucson Arts District Partnership, Inc)

- Kids Stop Child Care Center (Washington Metropolitan Area Transit Authority [WMATA], Montgomery County government, and corporate sponsors)

Partnerships between the community, transportation, and other public/private entities provide great incentives for the success of the neighborhood facility. Not only is the resource base expanded, but the motivation to succeed is increased. Partnerships are an effective tool for illustrating commitment to a community. Such commitment was very instrumental in the success of all of the facilities featured in this report.

\section{Cost Considerations}

Obviously, the costs of a neighborhood intermodal transfer facility will greatly depend upon the type of facility needed. As illustrated in the case studies, transit centers and park and

\footnotetext{
${ }^{12}$ Project for Public Spaces, Inc. 1997. The Role of Transit in Creating Livable Metropolitan Communities. New York: Federal Transit Administration, TCRP Report 22.
} 


\section{Neighborhood Intermodal Transfer Facilities}

ride lots may have greater land requirements than local transit stops. However, innovative partnering can aid in reducing the costs of facilities that greatly enhance Florida neighborhoods. A few suggestions are listed below.

- $\quad$ Enter into inexpensive land leases with municipalities (usually feasible for local transit stops or park and ride facilities)

- $\quad$ Develop shared use park and ride facilities

- Participate in joint development with community centers or other neighborhood entities

- Eliminate potential sites with high environmental concerns

- Capitalize on advertisement opportunities

- Reduce land requirements by minimizing building coverage (in the case of transit centers) 
Neighborhood Intermodal Transfer Facilities

Table 16

Case Study Facility Costs

\begin{tabular}{|l|c|c|c|}
\hline \multicolumn{1}{|c|}{ Facility } & Land Costs $(\$)$ & $\begin{array}{c}\text { Construction/Amenities } \\
\text { Costs }(\$)\end{array}$ & $\begin{array}{c}\text { Total Facility Costs } \\
(\$)\end{array}$ \\
\hline Margate Terminal & $\$ 0^{\mathrm{a}}$ & $\$ 15,000$ & $\$ 15,000$ \\
\hline G.I. Joe Park and Ride & $\$ 0^{\mathrm{a}}$ & $\$ 30,000^{\mathrm{b}}$ & $\$ 30,000$ \\
\hline Washington Shores & $\$ 0^{\mathrm{a}}$ & $\$ 249,000$ & $\$ 249,000$ \\
\hline Wellston MetroLink $^{\mathrm{c}}$ & -- & $\$ 1,500,000$ & $\$ 1,500,000$ \\
\hline Fisher's Landing & $\$ 5,000,000^{\mathrm{d}}$ & $\$ 4,500,000$ & $\$ 9,500,000$ \\
\hline Columbia Station & $\mathrm{e}$ & $\$ 9,000,000$ & $\mathrm{e}$ \\
\hline
\end{tabular}

${ }^{a}$ land was not purchased by facility developer

${ }^{\mathrm{b}}$ includes lighting, lot sweeping/maintenance, signage, and restriping/resealing lot

${ }^{c}$ right -of-way and costs for original costs of platform construction unknown; construction costs provided above relate to enhancements (landscaping, pedestrian and passenger amenities)

includes environmental preparation of land

${ }^{\mathrm{e}}$ breakdown of costs unknown

Obviously, costs play a significant role in what can be developed in an area; however, it is important to stress that the two most expensive case study facilities (Fisher's Landing and Columbia Station) involve elaborate buildings that house community and customer service related activities. While these activities have surely enhanced the facility, they are not necessarily required to successfully achieve intermodal integration. Intermodal transfer facilities around the United States have successfully integrated community activities through less expensive means such as open-air markets. In addition, transit customer service measures can also be achieved through less formidable means, such as the use of the manned kiosks. Such kiosks would be significantly less expensive, yet still allow the transit agency to provide information through personal interaction. 
Neighborhood Intermodal Transfer Facilities

\section{Conclusion}

"Seamless" travel is not just an opportunity to be afforded to those traveling from downtown or urban areas. On the contrary, intermodal transportation alternatives should be available to Floridians where they live and where they work, play, or shop. These alternatives can best be presented by placing intermodal transfer facilities within neighborhoods. The size and type of these facilities depend on the resources of those responsible for development and the needs of the community aimed at serving.

In addition to determining the facility type and dimensions, it is important to incorporate public involvement in the planning, design, and operational processes so that the community has ownership of its neighborhood intermodal transfer center. As was illustrated through the case studies presented in this report, facility design should embody elements that maximize passenger safety and convenience and allow for effective integration between modes.

While each of the facilities profiled exhibits different types of services and achieves multimodal compatibility through various means, they all demonstrate similar features regarding safety, accessibility, transferability, pedestrian and bicycle accommodation, passenger amenities, community involvement, and partnership participation. These features may have significant roles in the creation of intermodal transfer facilities in Florida neighborhoods.

In particular, intermodal transfer facilities have a place in a variety of Florida neighborhood types. The number of gated or secluded subdivisions is growing in Florida and it is critical that attempts are made to introduce transportation alternatives to these types of communities. Similarly, historic or existing Florida neighborhoods are also suitable areas for intermodal facilities as many of these types of communities have pre-existing pedestrian infrastructure. Florida communities with moderate-to-high levels of pedestrian traffic are 


\section{Neighborhood Intermodal Transfer Facilities}

also good candidates for neighborhood intermodal transfer facilities as they may provide a strong base for public transportation ridership. For similar reasons, those communities with many people who have no access to automobiles are also potential locations for neighborhood intermodal transfer facilities.

Neighborhood intermodal transfer facilities could also be appropriately placed near collegiate and retirement communities, as well as neighborhood shopping centers. Each of these environments could presumably present a strong base for support of intermodal travel options, either because they are often origination or destination points for many persons who do not have access to automobiles or prefer not to drive.

In any case, intermodal transfer facilities have a tremendous role in creating more livable neighborhoods. Throughout the country, public transportation has been the impetus to transit-oriented development creating a great environment for pedestrian, bicycle, transit, and automobile integration. As technological advances improve, Floridians will be afforded better opportunities to make informative travel decisions and increase the likelihood of traveling between modes. Until the time at which such technological applications are developed and filtered to neighborhoods throughout the state, it is imperative that transportation entities continue to participate in the development of neighborhood transfer facilities with emphasis on integrating modes through design techniques and amenity enhancements. 
Neighborhood Intermodal Transfer Facilities

Referenced Materials

Alschuler, Karen B. and Sarah B. Smith. April 1997. Transfer and Development: St. Louis MetroLink. Urban Land 56 (4): 38-41,77-78.

Box, Paul, Richard Hocking, Robert Grady, and Wulf Grote. 1992. Informational Report: The Location and Design of Bus Transfer Facilities. Washington, DC: Prepared by the ITE Technical Committee 5C-1A.

Glatting, Jackson, Kercher, Anglin, Lopez, Rinehart Inc. in association with HerbertHalback and Associates. 1994 (Revised in 2000 by Lynx). Central Florida Mobility Design Manual. Prepared for the Central Florida Regional Transportation Authority.

Herbert-Halback, and Associates Inc. 1994 (Revised in 2000 by Lynx). Customer Amenities Manual. Prepared for Central Florida Regional Transportation Authority (Lynx).

Horowitz, Alan and Nick Thompson. 1994. Evaluation of Intermodal Passenger Transfer Facilities: Final Report. Washington, DC: Federal Highway Administration, DOT-T-9502.

Implementing Bicycle Improvements at the Local Level: Bike Guide Online. 1998. Prepared by the Federal Highway Administration. Accessed at www.bikewalk.org/bike guide online.htm (August 2001).

Kimley-Horn and Associates Inc. 1998. Alternative for Intermodal Improvements in MiamiDade County: Final Report. Miami: Miami-Dade Metropolitan Planning Organization.

Project for Public Spaces Inc. 1997. The Role of Transit in Creating Livable Metropolitan Communities. New York: Federal Transit Administration, TCRP Report 22.

Rabinowitz, Harvey Z., Edward A. Beimborn, Peter Lindquist, and Donna M. Opper. 1989. Market Based Transit Facility Design. Washington, DC: UMTA, DOT-T-89-12

Sacramento Regional Transit District. 1991. Design Guidelines for Bus and Light Rail Facilities.

Solar Lighting. 2001. "Solar Lights at Long Beach Stops". Accessed at http://www.solarlighting.com/transit1.htm (July 2001).

Tri-County Metropolitan Transportation District of Oregon. 1996. Planning Design for Transit Handbook: Guidelines for Implementing Transit-Supportive Development. 
Neighborhood Intermodal Transfer Facilities

United States Department of Transportation Intermodal Terminal Committee. 1994. Intermodal Passenger Terminal Facilities Project Summaries: A Compendium of Proposed, Active, and Completed Intermodal Passenger Terminal Facilities. Washington, DC: U.S. Department of Transportation.

WalkBoston. 1998. Improving Pedestrian Access to Transit: An Advocacy Handbook. Washington, DC: Federal Transit Administration, FTA-MA-80-X008. 


\section{Contacts List}

\section{Margate Terminal (Margate, Florida)}

Lucas, Gerry

Director, Margate Inner-City Transit

(954) 972-8126

Glucas@margatefl.com

Fossa, Robert

Senior Planner, Broward County Transit

(954) 357-8336

Rfossa@broward.org

\section{Washington Shores Superstop (Orlando, Florida)}

Jamison, Doug

Project Manager, Lynx

(407) 841-2279

Djamison@golynx.com

Jordan, Terry

Associate Service Planner, Lynx

(407) 841-2279

Tjordan@golynx.com

\section{Columbia Station (Wenatchee, Washington)}

Bland, Lyle

Operations Director, Link Transit

(509) 663-6413

Lyle@linktransit.com 


\section{Neighborhood Intermodal Transfer Facilities}

\section{Fisher's Landing Transit Center (Clark County, Washington)}

Haggerty, Michael

Bus Service Development Manager, C-Tran

(360) 696-4494

Michaelh@c-tran.org

\section{G.I. Joe Park and Ride Facility (Portland, OR)}

Park, Young

Manager of Capital Projects, Tri-Met

(503) 962-2138

Parky@tri-met.org

\section{Wellston MetroLink Station, St. Louis County, Missouri}

Bryant, Sharon

BSDA

(314) 982-1514

Sbryant@bsda.org

Davis-Wellington, Jackie

Vice President of Real Estate and Community Development

St. Louis County Economic Council

(314) 615-3962

Jackie-Wellington@stlouisco.com

Douglas, Fred

Manager of Service Development, BSDA

(314) 982-1514

Fdouglas@bsda.org

Smith, Sarah

Director of Arts in Transit Program, BSDA

(314) 982-1514

Ssmith@bsda.org

Appendix A - Questions to Guide Interviews and Site Visits 


\section{Neighborhood Intermodal Transfer Facilities}

Geographic and Demographic Data

Where is the facility located?

What is the area (dimensions) of the site?

What environmental and natural resources surround the site?

Do you have a demographic profile of the user of this facility?

\section{Attitudes}

How well is transit perceived in this area?

Has there been a move toward or away from transit in the past decade?

What is the distribution of travel modes (bus, rail, car, walk, bike)?

\section{Neighboring Activities}

What are the land use activities around the site?

Is the area blighted (or was it blighted prior to the transit facility)?

What is the development history of the area around the site?

What types of residential activity surround the facility (type, value, etc)?

\section{Facility Details}

What are the modes at the site?

If park and ride - how many spaces, what is the cost to drivers, how do they pay, what is usual capacity?

If buses - how many routes, are there bays, average number of passengers?

If bikes - what kind of storage; is it free; do buses have racks; average \# of users?

Rail - how many routes, average number of passengers, etc?

Is the facility tied to a bike path?

Are the sidewalks adequate for the facility?

Are the fares coordinated (if bus, rail, park and ride, etc) or universal?

Are there shelters, lights, benches, phones, schedule books, trash receptacles, newspaper stands, food or postal vending machines, retail kiosks, drinking fountains?

Is there real-time transit/rail information? 


\section{Neighborhood Intermodal Transfer Facilities}

Is there a transit information representative present?

Is the facility neighborhood oriented?

What is the age of the facility?

Is there sufficient space for patrons, buses, park and ride space, etc?

Are advertisements placed in the facility?

Are there artistic amenities -like public space art or historical identifiers?

Is the facility covered? Climate-controlled?

Is there adequate space for bus ingress/egress?

Who maintains the facility?

Are crime statistics tracked for the facility?

Is the area landscaped? Were CPTED concepts involved?

Is the facility equipped for the disabled?

What precautions are taken for safety? Guards, surveillance cameras, etc?

What are the hours that the facility is open?

What steps were taken to ensure compatibility of mode schedules?

\section{Design Process}

Who was involved with the design of the facility?

What design criteria were used?

Are there design criteria that are preset for facilities (by your agency, the city, the state, etc)?

Site selection - was the site selected because a passenger source already existed? Was this an existing facility that has been remodeled/upgraded, revamped to accommodate its present arrangements?

\section{Public Involvement}

What was the level of public involvement in the planning of the facility?

What were the goals and objectives when planning this facility?

\section{Funding}

Who owns the facility site?

How was the feasibility study funded?

How was the design and planning funded?

How was the construction funded? 


\section{Neighborhood Intermodal Transfer Facilities}

How are operations and maintenance funded?

Were their unusual obstacles to obtaining funding?

How was the funding secured? What process or techniques were used?

Was private funding pursued? Acquired?

What are the annual operations and maintenance costs of this facility (what does that include)?

\section{Other Obstacles}

Provide details of obstacles to the development of this facility? With funding, design, community support, coordinating modes?

Were there any environmental concerns with the development of this facility?

Were rezoning or land use changes involved?

Impact

What impacts has this facility had on the community? Transit usage? Congestion?

Is there a noticeable change in crime in the vicinity of the facility?

Does the surrounding community seem receptive to the facility? Is there resistance to its presence?

How was the community's image incorporated into the facility?

Was the architectural design reflective of the community, the city, or something else?

\section{Assessment}

Are there design issues that you wish were addressed differently?

Are there things that have had to be modified since operation began?

What changes need to be made to make this facility better?

Will this facility serve as a model for others in the area? Why or why not? 